\title{
Determinants and consequences of a voluntary turn away from IFRS to local GAAP: Evidence from Switzerland
}

\author{
Peter Fiechter*, University of Neuchatel \\ Jerome Halberkann, University of Zurich \\ Conrad Meyer, University of Zurich
}

European Accounting Review (forthcoming)

First draft: December 2012

This version: August 2017

\begin{abstract}
We examine determinants and consequences of a turn away from IFRS to local GAAP, thereby exploiting a unique feature of the Swiss setting in which listed firms are allowed to switch from IFRS to Swiss GAAP, all else being equal. We posit that net benefits of IFRS are less for small firms with higher insider ownership. In addition, we predict that the net benefits of IFRS are not constant over time because of changes in IFRS and/or changes in firm-specific circumstances. To the extent that the switching firms' costs of IFRS reporting outweigh its benefits, we do not predict adverse capital-market effects after a switch. Consistent with predictions, we find that (a) small firms with higher insider ownership and fewer foreign investor holdings are more likely to switch, (b) increasing reporting costs as well as changes in firm-specific circumstances affect switching propensity, (c) switching firms substantially reduce their disclosures after they switch, and (d) switching firms neither experience a decrease in liquidity nor negative announcement returns. Overall, our findings are important for standard setters and securities regulators in shaping (future) reporting requirements for listed firms.
\end{abstract}

\footnotetext{
*Corresponding author: Peter Fiechter, Faculty of Economics and Business, University of Neuchatel, CH-2000 Neuchatel, Switzerland. We thank Hervé Stolowy (editor), two anonymous reviewers, Mary Barth, Ulf Brüggemann, Hans Christensen, Joachim Gassen, Markus Hitz, Thorsten Sellhorn, Laurence van Lent (previous editor), and workshop participants at University of Zurich, Humboldt University Berlin, the 2013 EAA Annual Congress, the 2014 AAA Annual Meeting, and the 2015 CARF conference for helpful comments.
} 


\section{Introduction}

Hail et al. (2010) point out that the substantial costs of IFRS reporting (e.g., preparation, certification, or proprietary costs) might not be justified by its benefits, particularly for small firms that raise the majority of their capital from banks or other private sources. Only few studies investigate firm-specific heterogeneity in the net benefits of IFRS. Daske et al. (2013) and Christensen et al. (2015) show that liquidity benefits and accounting quality, respectively, vary with firm-level reporting incentives. However, their findings are based on voluntary and mandatory IFRS adoption before and around 2005. Since 2005, IFRS have become substantially more detailed. In addition, changes in firm-specific circumstances over time likely also affect the net benefits of IFRS reporting. Therefore, the extent to which firms still realize net benefits from IFRS reporting remains an open question.

To shed light on the firm-specific (time-variant) net benefits of IFRS, we investigate the determinants and consequences of a turn away from IFRS. To isolate the effect of a change in accounting standards from potentially confounding effects of changes in enforcement, legal environment, and other institutional features (Christensen et al. 2013, Barth and Israeli 2013), we exploit a particular feature of the Swiss setting. In Switzerland, listed firms have the option to switch from IFRS to Swiss Accounting and Reporting Recommendations (hereafter, "Swiss GAAP"), all else being equal. While Swiss GAAP shares the same major reporting objective of a "true and fair view" with IFRS, the degree of complexity and number of accounting rules substantially differ across the two standards. In our sample between 2008 and 2013, 34 out of 141 (24\%) listed Swiss firms that are eligible for switching made use of this particular option (hereafter, "switching firms").

We posit that the net benefits of IFRS reporting are lower for small firms with higher insider ownership. Compared to large firms, small firms have higher fixed costs (Hail et al. 2010) and realize fewer benefits (Diamond and Verrecchia 1991) from greater disclosure. In 
addition, while insiders have private information, outsiders must rely on public accounting reports for monitoring purposes (Jensen and Meckling 1976). Based on this theory, empirical findings of Ruland et al. (1990) and Christensen et al. (2015) suggest a negative relation between insider ownership and the level of comprehensive disclosure. Therefore, firms with high insider ownership likely realize fewer benefits from IFRS.

We predict that firms switch when the perceived net benefits of IFRS become lower than those under Swiss GAAP. As mentioned previously, small firms with high insider ownership realize fewer net benefits from IFRS reporting. An increase in reporting costs due to changes in IFRS can thus trigger a switch for such firms. In addition, changes in firm-specific circumstances (e.g., decrease in size or increase in insider ownership) affect the net benefits of IFRS reporting, and in turn, alter the likelihood to switch accounting standard. ${ }^{1}$ To the extent that IFRS reporting costs outweigh its benefits, we predict that switching firms can reduce the level of disclosure without facing adverse capital-market effects.

Given our small sample size, we conduct several tests that collectively shed light on the determinants and consequences of switching from IFRS to Swiss GAAP. First, using firms' press releases, we analyze their stated reasons for the switch. We find that firms most frequently provide the following reasoning for their switch to Swiss GAAP: the high costs of complying with IFRS, increasing complexity of IFRS, and few perceived transparency benefits of IFRS when compared to Swiss GAAP. Consistent with these statements, we find that preparation and certification costs under IFRS have indeed increased since 2005, as documented by the more pronounced increase in both page numbers of financial statements and audit fees for IFRS firms than for firms that never changed their accounting to IFRS (hereafter, "Swiss GAAP stayers").

1 There is a potential third explanation as to why firms turn away from IFRS-i.e., firms overestimated the net benefits when adopting IFRS. However, in this paper, we do not investigate this potential explanation because (a) empirically testing whether firms overestimated IFRS-related net benefits is inherently difficult, and (b) our paper focuses on determinants and consequences of a turn away from IFRS, not on the adoption of IFRS. 
Second, to examine switching determinants not stated by the firms, we conduct a probit regression, a hazard model, and a linear probability model with firm fixed effects. In addition to our main variables of interest (size and ownership structure), we control for other firm characteristics such as growth, profitability, and leverage - identified by the literature as associated with accounting standard choices (e.g., Cuijpers and Buijink 2007), "going dark" decisions (Leuz et al. 2008), or reporting incentives (Daske et al. 2013). Furthermore, we control for the proportion of goodwill, early adoption of IFRS, and foreign investor holdings, all of which capture specific features of the Swiss setting. We find that smaller firms with high insider ownership and fewer foreign investor holdings are more likely to switch. In addition, consistent with the potential proprietary costs of IFRS disclosures, more profitable firms are more likely to switch. Findings from the hazard model and the linear probability regression indicate that small firms with higher insider ownership switch earlier and that firms with increasing (decreasing) insider ownership (size) are more likely to switch, respectively.

Third, to examine whether switching firms change their financial reporting, we compare annual reports before and after the switch. We find that firms substantially reduce their disclosures. For example, the number of pages in the notes to financial statements is reduced, on average, by 11 pages (30\%), whereas the reporting of the control group remains essentially the same. In addition, while $91 \%$ of the switching firms disclose information on earnings per segment (e.g., EBIT) under IFRS, only 38\% disclose such information after the switch. This finding is consistent with the probit results, indicating that switching firms seek to avoid the proprietary costs of IFRS disclosures. Moreover, the book value of equity under Swiss GAAP is substantially lower $(16 \%)$ than restated IFRS amounts, mainly because switching firms make use of the Swiss GAAP option to set off their goodwill against equity. Our descriptive 
evidence further reveals that mean audit fees significantly decrease by $8 \%$, consistent with lower certification costs under Swiss GAAP than under IFRS.

Fourth, to investigate the effect of a switch on liquidity, we use both a univariate and a multivariate difference-in-differences (DID) design. Our univariate tests compare switching firms' proportional bid-ask spreads and the percentage of zero returns 40 trading days before and after the switching announcement, after the publication of the first annual report under Swiss GAAP, and two years after publication. To control for general trends and self-selection bias, we use index-matched, size- and industry-matched, propensity score-matched (PSM), and Swiss GAAP-matched control groups. Our univariate findings do not suggest that the switching firms' liquidity decreases after the switch.

In the multivariate DID, we (a) control for differences in share volatility, share turnover, and market value across switching and non-switching firms; and (b) increase the number of observations by using quarterly bid-ask spreads and zero returns from Q1 2008 to Q2 2015. We find no increase in the bid-ask spreads of switching firms in quarters after the switching announcement or after the publication of the Swiss GAAP report. In addition, the slight increase in the percentage of zero returns after the switch is neither statistically nor economically significant.

Fifth, we examine stock returns at the announcement date. On the one hand, a decrease in liquidity (if any) might result in higher costs of capital (Diamond and Verrecchia 1991) and thus negative stock returns. On the other hand, investors might reward the lower costs of complying with Swiss GAAP than with IFRS. We find that approximately half of the switching firms exhibit negative stock returns around the switching announcement. Mean returns are neither significantly different than the returns of the control groups nor economically large. We also find no differences in announcement returns for the subsample of switching firms with more dispersed ownership. 
Overall, our results suggest that-for a certain type of firm (i.e., small firms with high insider ownership) - the current IFRS might not be the optimal reporting outlet. While switching firms can substantially reduce disclosure levels (thereby saving preparation, audit, and proprietary costs), on average, they do not experience adverse capital-market effects. Therefore, the accounting rules and disclosure requirements under IFRS are likely not incrementally more useful than Swiss GAAP for investors of small firms with high insider ownership. This explanation is consistent with the switching firms' statements in their press releases and the findings from a survey of small and medium-sized entities (SMEs) in Switzerland (source: Meyer 2009).

An alternative explanation for the finding that certain switching firms do not experience negative liquidity consequences is that they never obtained liquidity benefits around IFRS adoption because of "non-serious" IFRS application. However, (a) the rather high level of enforcement in Switzerland likely mitigates non-serious application of IFRS, and switching firms are not more prone to regulatory actions than non-switching firms; (b) our descriptive evidence documents that firms seriously change their reporting after they switch; and (c) additional analyses suggest that, around IFRS adoption in 2005, the liquidity effects of switching firms are positive and comparable to those of non-switchers. Therefore, while we acknowledge that the commitment to transparency might differ across switching and nonswitching firms (Daske et al. 2013), non-serious application of IFRS cannot entirely explain our findings. In addition, we do not find that switching firms systematically increase alternative reporting channels (i.e., number of press releases, ad hoc publicity, or number of conference calls) to compensate for the disclosure reduction.

Our findings contribute to the literature in three ways. First, we provide empirical evidence on the discussion as to whether the current "one-size-fits all" reporting approach for listed firms is optimal (Hail et al. 2010, Ernst \& Young 2013, IASB 2013a, IASB 2013b, 
Hoogervorst 2015). By showing that switching firms can substantially reduce their disclosure without experiencing adverse capital-market effects, our empirical evidence points towards the explanation that the costs of IFRS reporting outweigh its benefits for certain firms (i.e., small firms with high insider ownership). As 114 countries require IFRS for listed companies, and as $82 \%$ of the listed companies worldwide are within the small and mid-cap segment (WFE 2013), this finding should be of particular interest for standard setters and securities regulators. Second, we add to the literature on firm-specific heterogeneity in the costs and benefits of IFRS. We complement the findings of Daske et al. (2013) and Christensen et al. (2015) by showing that the net benefits of IFRS reporting vary not only with different reporting incentives but also across time. Third, our findings also lend some support to the explanation that IFRS reporting per se (i.e., without concurrent changes in the institutional or firms' reporting environment) does not exert a first-order effect on liquidity (Christensen et al. 2013, Barth and Israeli 2013).

Our study has some limitations. First, our sample of 34 switching firms is relatively small. However, collectively, our tests shed light on firm-specific (time-variant) costs and benefits of IFRS reporting. Second, because the switch is a choice, our liquidity analyses might suffer from self-selection bias. We attempt to address that concern by using several control groups, including a PSM control group. Finally, and most importantly, we emphasize that the switching firms are primarily small and mid-cap companies and that Switzerland constitutes a strong institutional environment. Therefore, we caution against generalizing our findings to countries with weak institutional environments, and we caution from interpreting our findings as evidence that the net benefits of IFRS have become negative for all firms regardless of their size and ownership structure.

The remainder of the paper is organized as follows. Section 2 outlines the institutional background, differences between IFRS and Swiss GAAP, related literature, and empirical 
predictions. Section 3 explains the research design, Section 4 describes our sample, and Section 5 presents the empirical results. Section 6 provides additional analyses and Section 7 concludes.

\section{Background and Hypotheses}

\subsection{Institutional background}

Unlike in European Union (EU) countries, IFRS is not implemented in Swiss law. For firms with quoted equity instruments, the SIX Swiss Exchange (SIX) offers a choice between the International Reporting Standard and the Swiss Reporting Standard. In addition, the SIX requires specific admission standards for investment firms, real estate companies, and depository receipts (SIX 2015a). While a firm that uses IFRS or U.S. GAAP is classified under the International Reporting Standard, a firm using Swiss GAAP is classified under the Swiss Reporting Standard (SIX 2015b). ${ }^{2}$

Besides the different accounting standard requirements, the listing rules do not differ across the International and the Swiss Reporting Standard (SIX 2015a). Firms in both listing standards are subject to the same regulation (i.e., SIX Exchange Regulation) and regulatory authority (i.e., Regulatory Board). Furthermore, the minimum requirements for book value of equity of CHF (Swiss Franc) 2.5 million and for the free float of $20 \%$ do not differ. Furthermore, both listing standards require semi-annual reporting, ad hoc publicity, disclosure of management transactions, and corporate governance reporting (SIX 2015a). Finally, the

2 Note that, during our sample period, the SIX used other labels for its trading segments: the "Main Segment" comprised IFRS/U.S. GAAP firms, whereas the "Domestic Segment" comprised Swiss GAAP firms. Besides the different reporting requirements (IFRS/U.S. GAAP vs. Swiss GAAP), the former SIX trading segments differed solely regarding the minimum capital requirements (CHF 25 million vs. CHF 2.5 million) and the free float market capitalization (CHF 25 million vs. 5 million). However, as these requirements apply only on the first trading day, potential violation during the listing neither triggers any SIX actions nor forces the firms to change the trading segments. Therefore, differences in the trading segment do not explain switch decisions. Neither does the institutional environment change for firms after their switch. 
level of enforcement does not substantially vary across listing standards (see analyses in Section 6.1.1).

Overall, in Switzerland, firms can switch from IFRS to Swiss GAAP without experiencing any change in the legal environment, listing rules, or other reporting requirements. ${ }^{3}$ Therefore, the Swiss setting allows us to investigate the effect of a change in accounting standard while holding other institutional factors constant.

\subsection{Differences between IFRS and Swiss GAAP}

Similar to IFRS, Swiss GAAP is based on the "true and fair view" principle (IASB 2009, FER 2012). ${ }^{4}$ In particular, Swiss GAAP does not accept "hidden reserves", in contrast to the minimum accounting requirements by the Swiss Law on Commercial Accounting and Financial Reporting (FER 2014). While IFRS concretize the "true and fair view" principle with detailed rules, Swiss GAAP relies rather on general concepts without specifying implementation or exceptions for special cases. Accordingly, Swiss GAAP comprises around 200 pages for 25 standards, compared to over 2000 pages under IFRS for 38 standards and 25 interpretations. Similarly, Swiss GAAP requires fewer disclosures in the notes to financial statements.

The most important accounting differences between IFRS and Swiss GAAP are goodwill accounting, pension accounting, and segment reporting. Under Swiss GAAP, goodwill is either (a) capitalized at cost and then amortized over its useful life (maximum of 20 years) with regular impairment tests, or (b) set off against equity at initial recognition (i.e., the acquisition date). The impairment-only-approach under IFRS, whereby goodwill is capitalized and impaired only if necessary, is not permitted under Swiss GAAP. If goodwill is set off

3 Between 2008 and 2013, 34 firms switched from IFRS to Swiss GAAP, and one firm switched from U.S. GAAP to Swiss GAAP. No firm switched from Swiss GAAP to either IFRS or U.S. GAAP.

4 Although the revised IFRS framework (issued in September 2010) no longer explicitly mentions the principle "true and fair view", the fundamental qualitative characteristic "faithful representation" (IASB 2011, para. FQC5) is consistent with financial statements that convey a true and fair view. 
against equity, the effects of a theoretical capitalization and amortization are disclosed in the notes to financial statements.

Pension accounting under Swiss GAAP does not distinguish between defined contribution plans and defined benefit plans. Based on contracts, regulations, and legal requirements, a pension liability or a pension asset is recognized in the balance sheet. Any differences between the estimated liability or the estimated asset at the beginning and at the end of the reporting period are recognized in the income statement. IFRS distinguishes between defined contribution plans and defined benefit plans. While the accounting for defined contribution plans is straightforward, the accounting for defined benefit plans under IFRS is complex and requires actuarial assumptions. The accounting for a defined benefit plan requires the calculation and recognition of a deficit (surplus) as a net defined benefit liability (asset). While service costs and net interest on the defined benefit liability (asset) are recognized in the income statement, re-measurements of the net defined benefit liability (asset) are recognized in other comprehensive income. In addition, IFRS requires more extensive disclosures on the assumptions and calculations than Swiss GAAP.

IFRS 8 (effective as of January 1, 2009) requires information on operating segments, products and services, geographical areas, and major customers. For each reportable segment, an entity has to disclose a measure of earnings (e.g., EBIT), total assets and liabilities, and other information (e.g., depreciation, amortization, and additions to non-current assets). In contrast, under Swiss GAAP, the required segment disclosures are substantially less comprehensive. For each business segment and geographical market, only total revenues must be disclosed. If business segments are not significantly different from one another, no segment information need be provided.

Another major difference between IFRS and Swiss GAAP is the extent to which standards are subject to change over time. Between 2005 and 2013, the International 
Accounting Standards Board (IASB) issued a total of 64 new standards, interpretations, or amendments to existing standards (source: own data collection). In particular, the new standards IFRS 7 Financial Instruments: Disclosures, IFRS 8 Segment Reporting, IFRS 10 Consolidated Financial Statements, or the revision of IFRS 3 Business Combinations likely have a substantial impact on the accounting and disclosures of IFRS firms. In addition, between 2005 and 2013, the IASB issued 52 exposure drafts and 12 discussion papers, potentially affecting the future accounting requirements for IFRS firms. Tracking of IFRS changes, evaluation of the impact for new or revised standards, and implementation of these changes, all of which increase the IFRS reporting costs. While Swiss GAAP has also been subject to changes between 2005 and 2013, these changes are less extensive than those of IFRS (Deloitte 2014, FER 2014).

Findings from a survey (source: Meyer 2009) of SMEs in Switzerland support the notion that perceived costs and benefits differ across IFRS and Swiss GAAP. ${ }^{5}$ Figure 1 shows that most respondents — regardless of whether they are listed or not—find that the advantages of Swiss GAAP include less complexity, volume, and implementation costs. However, respondents perceive the higher international awareness as an advantage of both IFRS and IFRS for SMEs.

[Figure 1 here]

\section{$2.3 \quad$ Related literature}

Studies on voluntary and mandatory IFRS adoption generally document positive capitalmarket effects (e.g., Leuz and Verrecchia 2000, Li 2010, Landsman et al. 2012). Daske et al.

\footnotetext{
5 The survey initially contacted 4,848 non-listed and 55 listed Swiss SMEs (i.e., firms with less than 500 employees). While 849 (17.5\%) and 20 (36.4\%) non-listed and listed firms, respectively, returned a valid questionnaire, the number of responses on the perception of Swiss GAAP versus IFRS and IFRS for SMEs is lower: between 359 and 414 non-listed firms and 19 listed firms (see Figure 1).
} 
(2008) show that market liquidity increases around mandatory adoption of IFRS in countries with strong enforcement and greater incentives for transparent reporting. Christensen et al. (2013) further indicate that the capital-market benefits around IFRS adoption are attributable to concurrent changes in reporting enforcement rather than to the change in accounting standard. However, disentangling IFRS benefits from enforcement benefits is difficult, particularly when changes in enforcement are made concurrently with IFRS adoption (Barth and Israeli 2013).

While most of the IFRS literature focuses on the cross-sectional differences of IFRS benefits at the country level, Daske et al. (2013) highlight the importance of firm-level reporting incentives. They argue that capital-market effects should be stronger for firms with the intent to increase their commitment to transparency than for firms that adopt IFRS without the intent to provide more or better accounting information (i.e., "label adopters"). Consistent with their predictions, Daske et al. (2013) find that label adopters do not realize liquidity benefits around IFRS adoption. Using a single-country setting of German firms, Christensen et al. (2015) find that improvements in accounting quality vary with firm-specific reporting incentives (e.g., connections with banks and insider ownership).

To investigate the effect of voluntary disclosure on the cost of capital, Hail (2002) uses a sample of 73 listed Swiss firms, because the impact of voluntary disclosure is likely more easily detectable in a low disclosure environment with considerable reporting discretion. Consistent with predictions, Hail (2002) finds substantially lower cost of capital for firms with higher disclosure scores. Also motivated by the low reporting requirements in Switzerland, Dumontier and Raffournier (1998) investigate why Swiss firms voluntarily comply with International Accounting Standards (IAS). They find that firms complying with 
IAS are larger and have more foreign sales. ${ }^{6}$ However, both studies investigate the Swiss setting before the year 2000, a period in which the Swiss accounting rules were less stringent, tolerating "hidden reserves". 7 Yet, the extent to which the findings from these studies can be translated into the current discussion of cost and benefits of IFRS - with the current Swiss GAAP as alternative reporting outlet—remains unclear.

Only few papers investigate the implications of a reduction in disclosure. Leuz et al. (2008) investigate the causes and consequences of firms' decisions to deregister and cease SEC reporting (i.e., "going dark"). Their findings suggest that such firms experience large negative abnormal returns. Hitz and Müller-Bloch (2014) investigate German firms that opt into an unregulated market. While their findings suggest a significantly negative market reaction to "going gray" announcements, abnormal returns vary in the cross-section.

The Swiss setting has the advantage that we can isolate the effect of a change in accounting standard while holding the institutional environment plausibly constant. ${ }^{8}$ In addition, the small sample size allows us to directly investigate whether firms actually change their reporting. Most studies simply focus on whether or not a firm applies IFRS—without having a closer look at actual changes in reporting. While Daske et al. (2013) point out that IFRS application is heterogeneous across firms, they rely on proxies for firms' reporting changes (i.e., changes in firm characteristics, accrual-based earnings quality, and analyst following) to identify serious and label adoption of IFRS. We exploit the specific features of our setting to shed further light on the firm-specific (time-variant) costs and benefits of IFRS,

6 Dumontier and Raffournier (1998) also predict that firms with greater ownership diffusion are more likely to voluntarily comply with IAS. However, while the univariate tests are consistent with this prediction, the multivariate findings are insignificant.

7 While the accounting rules under Swiss company law explicitly allow ,hidden reserves“, the former Swiss GAAP (i.e., before the year 2000) remained largely silent on this issue.

8 Switching firms (a) are subject to the same regulations, (b) remain under supervision of the same regulatory authority, (c) are subject to the same level of enforcement, and (d) continue to comply with other reporting requirements such as interim reporting, corporate governance reporting, and ad hoc publicity. 
thereby providing evidence on the discussion as to whether the current "one-size-fits-all" reporting approach for listed firms is optimal.

\subsection{Empirical predictions}

IFRS reporting imposes both direct costs (e.g., preparation and auditing of reports) and indirect costs (e.g., release of proprietary information). Because these costs usually have fixed components, IFRS reporting can be particularly burdensome for small firms (Hail et al. 2010). In addition, small firms realize fewer benefits from more disclosure (Diamond and Verrecchia 1991) than large firms. The realized benefits from IFRS reporting vary not only with size but likely also with the ownership structure. While insiders have private information, outsiders must rely on public accounting reports for monitoring purposes (Jensen and Meckling 1976). Based on the theory of Jensen and Meckling, Ruland et al. (1990) and Eng and Mak (2003) find that firms with higher insider ownership are less likely to provide management forecasts of earnings and have lower disclosure scores, respectively. In addition, Christensen et al. (2015) find that German firms with closer connections to inside shareholders are more likely to delay IFRS adoption, consistent with lower incentives for more comprehensive accounting standards. If the costs of reporting are not justified by its benefits, imposing a given disclosure level can result in net costs to certain firms (Hail et al. 2010, Johnstone 2015).

IFRS have become substantially more detailed over the past decade (see e.g., Section 2.2). In a survey conducted by the IASB, most preparers of financial statements find that the IFRS disclosure requirements are "too extensive" (IASB 2013a). Moreover, certain stakeholders even express concerns about "disclosure overload" (e.g., Ernst \& Young 2013; IASB 2013a, IASB 2013b). Therefore, the reporting costs of IFRS have likely increased over time. While the IASB acknowledges these concerns about increasing complexity and 
disclosure overload, it remains unclear as to whether a reduction in disclosure requirements would be detrimental to investors (Hoogervorst 2015).

We predict that firms use the option to switch from IFRS to Swiss GAAP when the perceived net benefits of IFRS are smaller than those under Swiss GAAP. As outlined above, small firms with high insider ownership realize fewer net benefits from IFRS reporting. An increase in IFRS reporting costs further reduces net benefits for such firms. When the perceived net benefits of IFRS become smaller than those under Swiss GAAP, it is likely that the firms switch accounting standard. While an increase in reporting costs also decreases net benefits of large firms with dispersed ownership, their net benefits might be still sufficiently large to continue reporting under IFRS. Therefore, we predict that small firms with high insider ownership are more likely to switch from IFRS to Swiss GAAP.

Net benefits of IFRS reporting may also decline because of firm-specific changes over time. If, for example, firm size decreases due to business restructuring, this firm likely realizes fewer benefits but higher fixed costs of IFRS reporting. These changes in firmspecific circumstances might result in lower net benefits of IFRS than under Swiss GAAP. Similarly, an increase in insider ownership might lower the demand for public accounting information, thereby reducing the benefits of IFRS relative to Swiss GAAP. We thus predict that firms experiencing a decrease (increase) in size (insider ownership) are more likely to switch from IFRS to Swiss GAAP.

As outlined in Section 2.2, Swiss GAAP requires fewer disclosures than IFRS. Therefore, we expect that firms reduce their level of disclosed accounting information after switching from IFRS to Swiss GAAP, thereby saving preparation and audit costs. In addition, to the extent that firms switch because of proprietary cost considerations, we expect that firms also reduce the level of potential proprietary disclosures by taking advantage of the less detailed Swiss GAAP rules on segment reporting. To the extent that the disclosure level as required by 
IFRS exceeds investors' demand for public accounting information, we predict that switching firms can reduce disclosures without facing negative liquidity consequences. ${ }^{9}$

Stock market reactions to the announcement of a switch are twofold. On the one hand, decreasing liquidity (if any) leads to higher costs of capital (Diamond and Verrecchia 1991). Consistent with this explanation, Leuz et al. (2008) find large negative abnormal returns for firms that announce to cease SEC reporting. On the other hand, investors might reward the potential cost savings of a switch from IFRS to the less extensive Swiss GAAP. ${ }^{10}$ In sum, we do not expect large negative stock returns for switching firms at the announcement of their switch from IFRS to Swiss GAAP.

\section{Research Design}

\subsection{Determinants of a switch from IFRS to Swiss GAAP}

To examine the determinants of a switch to Swiss GAAP, we first collect and analyze firms' press releases on the reasons for switching. To examine switching determinants not stated by the firms, we conduct a probit regression. ${ }^{11}$ The probit regressions provide insights on the cross-sectional determinants to switch at a given point in time. We also use a hazard model to allow for cross-sectional differences in the timing of the switch. Finally, to examine whether changes in firm-specific circumstances drive switching behavior, we use a linear probability model with firm fixed effects.

\footnotetext{
9 In addition to the transparency effect, a change in accounting standards can also affect the comparability of accounting information (Daske et al. 2008) and, in turn, firm liquidity. However, the comparability effect of a switch from IFRS to Swiss GAAP is unclear. While switching from IFRS to Swiss GAAP reduces comparability with firms continuing to report under IFRS, it increases comparability with firms that never changed their accounting to IFRS (i.e., Swiss GAAP stayers).

10 The net effect on firm value might also be overshadowed by the announcement effect of the switch: the effect of the information that the switch reveals to market participants. As accounting changes might indicate that the firm wants to obfuscate poor performance by switching the accounting standard, market reactions are likely negative (Leuz et al. 2008). However, as Swiss GAAP shares the same major reporting objective of a "true and fair view" with IFRS, obfuscating poor performance is similarly difficult after a switch.

11 Using logit instead of probit regressions does not yield different findings.
} 


\subsubsection{Probit regression}

For switching firms (i.e., firms that switch from IFRS to Swiss GAAP during the sample period from 2008 to 2013), the dependent variable SWITCH equals 1 in the year of the announcement to switch, and is missing in the years before and after the year of the switch. For non-switching firms, SWITCH equals 0 throughout the sample period (equation (1)).

In Section 2.4, we predict that small firms with high insider ownership are more likely to switch. Therefore, our main explanatory variables for SWITCH are INSIDER and SIZE. We define INSIDER as the percentage of strategic share holdings of $5 \%$ or more held by employees or by individual investors. We define SIZE as the natural logarithm of total assets at the beginning of the year. ${ }^{12}$

$$
\begin{aligned}
& S W I T C H_{\mathrm{it}}=\beta_{0}+\beta_{1} I N S I D E R_{\mathrm{it}-1}+\beta_{2} S I Z E_{\mathrm{it}-1}+\beta_{3} G R O W T H_{\mathrm{it}-2}+\beta_{4} L E V_{\mathrm{it}-1}+\beta_{5} R O A_{\mathrm{it}} \\
& +\beta_{6} R E T_{\mathrm{it}}+\beta_{7} G W_{\mathrm{it}-1}+\beta_{8} E A R L Y_{\mathrm{i}}+\beta_{9} \text { FOREIGN }_{\mathrm{it}-1}+\text { YEAR }_{\mathrm{t}} \\
& +\operatorname{INDUSTR}_{\mathrm{i}}+\varepsilon_{\mathrm{it}}
\end{aligned}
$$

Following previous research (Cuijpers and Buijink 2007, Leuz et al. 2008), we control for financing needs, financial structure, and performance. High financing needs decrease the likelihood of a switch from IFRS to Swiss GAAP, as potential capital providers may require more detailed accounting disclosure to evaluate the firm. We use the average asset growth of the preceding two years $(G R O W T H)$ to proxy for financing needs. ${ }^{13}$ For financial structure, we include the debt-to-asset ratio $(L E V)$ at the beginning of the year. To the extent that higher leverage induces more agency costs and thus more demand for public disclosures (e.g., Meek et al. 1995), we expect a negative sign for $L E V$. However, if leverage proxies for the "inside

12 Our findings do not change when we use the log of market capitalization instead of total assets for firm size. In addition, the inclusion of an additional variable for whether the book value of equity is close to the SIX minimum requirements does not change our inferences.

13 When we use an alternative definition of growth, the market-to-book ratio, our main inferences do not change. 
orientation" of the firm because debt providers such as banks are typically less dependent on public disclosures (Cuijpers and Buijink 2007), we expect a positive sign for this variable.

To control for performance, we include the return on assets $(R O A)$ and annualized stock return $(R E T)$ during the announcement year. ${ }^{14}$ If firms intend to obfuscate poor performance under the new, less detailed accounting standard, we expect a negative sign for ROA and RET. However, to the extent that more profitable firms have incentives for reducing disclosures that will damage their competitive position (e.g., Wagenhofer 1990), we expect a positive association between ROA and SWITCH.

In addition to the main explanatory variables and controls used in prior studies, we include further variables (i.e., GW, EARLY, and FOREIGN) designed to capture specific features of the Swiss setting. Under Swiss GAAP, firms can set off goodwill against equity, thereby avoiding the risk of future impairments and preparation costs of the impairment test. Because the impairment risk increases with higher levels of goodwill, we predict that firms with a high proportion of goodwill to total assets $(G W)$ are more likely to switch from IFRS to Swiss GAAP.

Because IFRS became mandatory in 2005 for listed firms in the EU, many Swiss firms also adopted IFRS in 2005. However, some firms had already adopted IFRS prior to 2005. To the extent that the early adopters' commitment to transparent financial reporting is greater (Christensen et al. 2015), we expect them to be less likely to turn away from IFRS. We include the binary variable $E A R L Y$, which equals 1 if the firm adopted IFRS before 2005, and 0 otherwise.

Finally, we control for foreign investor holdings by including the proxy FOREIGN, which is defined as the percentage of strategic share holdings of $5 \%$ or more held in a country other than that of the issuer. We predict a negative sign for FOREIGN because foreign investors are

14 For the definition of $R O A$, we exclude potential accounting effects of the switch from IFRS to Swiss GAAP on net income. 
likely more familiar with IFRS than with Swiss GAAP, and thus a switch from IFRS to Swiss GAAP would be inconsistent with the foreign investors' demand for public accounting information. ${ }^{15}$ Depending on the specification, we also include year and industry fixed effects.

\subsubsection{Hazard model and linear probability regression}

We use a hazard model to examine firm characteristics associated with earlier switches. A hazard rate is the probability that the event will happen at time $t$ (e.g., Kiefer 1988, Petersen 1991). In our setting, the event is the switch from IFRS to Swiss GAAP, and the time at risk (i.e., time during which the event can occur) begins in 2006 and ends in $2013 .{ }^{16} \mathrm{We}$ adopt a parametric Weibull hazard model in which the dependent variable TIME_SWITCH_FE is a combination of TIME and whether the event $\left(S W I T C H \_F E\right)$ occurs. ${ }^{17}$ TIME is the time at risk from 2006 (value $=1$ ) until 2013 (value = 8). For switching firms, SWITCH_FE equals 1 in the year of the announcement to switch, equals 0 in the years prior to the switch, and is missing in the years after the switch. For non-switching firms, SWITCH_FE equals 0 throughout the time at risk. We use the same explanatory variables as in equation (1) except for the year and industry fixed effects. We predict that the hazard increases and decreases with INSIDER and SIZE, respectively.

In addition to the hazard model, we conduct a linear probability regression with firm fixed effects. We regress the dependent variable $S W I T C H \_F E$ on the explanatory variables in equation (1) except for the time-invariant variables EARLY and INDUSTRY, which are captured by the firm fixed effects. The linear probability model with firm fixed effects

\footnotetext{
15 In additional analyses, we also include the percentage of foreign sales to total sales as a proxy for the extent to which international comparability (with IFRS peers) is important. Because of missing data for a substantial number of firms, we do not include foreign sales in the main tests. However, the results based on the reduced sample of 405 observations yield no different inferences.

16 Note that the sample size differs from that in the probit regressions due to the longer investigation period (2006-2013) and the different definition of the dependent variable SWITCH_FE. However, our inferences do not change when we limit the time at risk to the period from 2008 to 2013.

17 Findings do not change when using an exponential hazard model or a Cox proportional hazard model.
} 
controls for time-invariant differences across firms, allowing us to interpret the coefficient estimates as changes in firm-specific circumstances explaining the switch. However, linear probability models can imply probabilities outside the [0, 1] interval (Wooldridge 2009).

\subsection{Reporting changes}

\subsubsection{Reporting changes after the switch}

To investigate the effect of a switch from IFRS to Swiss GAAP on firms' reporting, we analyze the change in disclosed financial information in the annual report, changes in segment reporting, reconciliation of shareholders' equity and net income from IFRS to Swiss GAAP, and changes in audit fees.

To analyze the disclosure change (e.g., number of pages in notes to financial statements) and the change in segment reporting (e.g., percentage of firms that disclose earnings per segment), we compare the last annual report prepared according to IFRS (e.g., 2012) to the first annual report prepared according to Swiss GAAP (e.g., 2013). To account for general trends in financial reporting, we use a propensity score matched (PSM) control group based on the model in equation (1). ${ }^{18}$ Because the PSM control group continues with IFRS reporting, we compare the IFRS report in the year before the matched treatment firm switches (e.g., 2012) with the IFRS report of the year in which the matched switching firm reports under Swiss GAAP (e.g., 2013).

To identify the effect of a switch on shareholders' equity and net income, we compare restated IFRS amounts to reported Swiss GAAP figures in the first annual report under Swiss GAAP (e.g., 2013). The reconciliation of shareholders' equity and net income from IFRS to Swiss GAAP reveals adjustments due to differences in goodwill accounting, pension accounting, tax effects, and other effects across the two standards.

\footnotetext{
18 We us a one-to-one nearest neighbor PSM without replacement.
} 


\subsubsection{Reporting changes since 2005}

To support the argument that IFRS reporting costs have increased over time, we investigate the changes in reporting (i.e., number of pages in the annual report, notes, and accounting principles) and audit fees since 2005. To control for general trends in reporting and audit fees over time, we use the Swiss GAAP stayers as the control group. We analyze reporting and audit fees for the switching firms and the Swiss GAAP stayers in the year 2005 and the year before the matched treatment firms switch from IFRS to Swiss GAAP. Because Swiss GAAP was arguably less subject to change than IFRS since 2005 (see Section 2.2), we predict a more pronounced increase in reporting and audit fees for the switching firms than for the Swiss GAAP stayers.

To examine whether the increase in IFRS reporting costs (if any) is not limited to switching firms, we also examine reporting and audit fee changes since 2005 for the PSM control group. We analyze reporting and audit fees for the switching firms and the PSM control group in 2005 and the year before the matched treatment firms switch from IFRS to Swiss GAAP. Because the PSM control group also applies IFRS, they should be subject to similar reporting and audit fee changes as the switching firms.

\subsection{Liquidity effects}

To the extent that the announcement of a change in accounting standard represents a credible change in the commitment to transparency, the effect on liquidity may occur prior to the actual publication of the report (Leuz and Verrecchia 2000, p. 115). Therefore, we first investigate the effect of the announcement to switch from IFRS to Swiss GAAP on liquidity $\left(t_{1}\right)$. The actual reduction of transparency (if any) occurs at $t_{2}$, when the first report under 
Swiss GAAP is published. ${ }^{19}$ Finally, we investigate the long-term effects of the switch at $t_{3}$, two years after publication of the first annual report under Swiss GAAP.

For the univariate DID, we measure liquidity via the proportional bid-ask spread and percentage of zero returns (e.g., Leuz and Verrecchia 2000; Daske et al. 2008). We calculate the bid-ask spread and percentage of zero returns for a period of 40 trading days before the switching announcement (pre $t_{1}$ ), after the announcement (post $t_{1}$ ), after publication of the first report under Swiss GAAP (post $t_{2}$ ), and two years after publication (post $t_{3}$ ). To account for general trends and self-selection bias, we use several control groups: index-matched, sizeand industry-matched, PSM, and Swiss GAAP-matched.

For the multivariate DID, we use a research design similar to that of Daske et al. (2008) and Christensen et al. (2013). We use quarterly data from Q1 2008 to Q2 2015, allowing us to investigate liquidity effects in the post-reporting period for late switchers (e.g., firms that switch in 2013). ${ }^{20}$ We regress the natural logarithm of the proportional bid-ask spread and percentage of zero returns (LIQUIDITY) on the indicator variable POST_SWITCH, which can be either POST_ANNOUNCE, POST_PUBL, or POST_PUBL_8Q (equation (2)). POST_ANNOUNCE equals 1 for all quarters of a switching firm after its announcement to switch; POST_PUBL equals 1 for all quarters of a switching firm after publication of the first report under Swiss GAAP; and $P O S T_{-} P U B L_{-} 8 Q$ equals 1 for a maximum period of eight quarters after publication of the first report under Swiss GAAP. We use the specification with POST_PUBL_ $8 Q$ to limit the likelihood that other events unrelated to the switch affect firms' liquidity. ${ }^{21}$

19 For example, if the switching announcement is in June 2009, the 2009 annual report is the first report under Swiss GAAP.

20 Our inferences hold when limiting the sample period to quarterly observations from 2008 to 2013 . In addition, our findings do not change when we exclude the five firms that switch after 2013 from the control group.

21 While the extended sample period until Q2 2015 enables us to investigate post-publication effects for late switchers, the post-publication period for early switchers is relatively long, increasing the likelihood that other events affect firms' liquidity after they switch. 
We control for differences in share volatility (RET_VOL), share turnover $\left(S H A R E \_T U R N\right)$, and market value $(M V)$. In addition, we include quarter and firm fixed effects. If liquidity decreases for the switching firms, the coefficient for POST_SWITCH is positive.

$$
\begin{aligned}
\text { LIQUIDITY }_{\mathrm{it}}=\quad & \beta_{0}+\beta_{1} \text { POST_SWITCH }_{i t}+\beta_{2} \log \left[R E T_{-} \text {VOL } L_{i t}\right]+ \\
& \beta_{3} \log \left[S H A R E_{\_} T U R N_{i t}\right]+\beta_{4} \log \left[M V_{i t}\right]+\text { QuarterFE }_{t}+\text { FirmFE }_{i}+\varepsilon_{\mathrm{it}}
\end{aligned}
$$

\subsection{Stock returns}

To examine effects of a switch from IFRS to Swiss GAAP on stock returns, we conduct an event study around the switching announcement. We measure the stock returns for three event windows around the announcement day. We use a one-day and a two-day window after the announcement (Leuz et al. 2008). To capture stock market reactions to possible information leaks before the official announcement of the switch, we use a third window that comprises the five days before and the five days after the announcement (including the announcement date). We adjust the raw returns of the switching firms by returns of indexmatched, size- and industry-matched, PSM, and Swiss GAAP-matched control groups.

\section{Sample Description}

We identify a total of 34 firms that switched from IFRS to Swiss GAAP during the sample period from 2008 until 2013: 1, 7, 10, 4, 4, and 8 firms switch in the years 2008, 2009, 2010, 2011, 2012, and 2013, respectively. For the probit regression (equation (1)), in each sample year, we match the switching firms to the eligible IFRS firms. Firms for which the switch from IFRS to Swiss GAAP is not an option are not considered eligible, including (a) 
firms that do not apply IFRS (e.g., U.S. GAAP or Swiss GAAP stayers), (b) firms whose primary stock exchange is not the SIX, and (c) investment entities that cannot switch to the Swiss Reporting Standard. ${ }^{22}$ Our control sample (i.e., eligible IFRS firms) is further reduced because of missing data in Thomson Reuters for the probit regression variables. These procedures yield a control sample of 628 (107) eligible IFRS firm-years (unique firms) from 2008 to $2013 .^{23}$

Table 1 shows the descriptive statistics for the 34 switching firms (Panel A) and the 628 IFRS firm-years (Panel B). Consistent with our predictions, the percentage of insider ownership is significantly higher (untabulated t-stat $=4.19$ ) for switching firms $(35 \%)$ than for non-switching firms (17\%). In addition, switching firms are substantially smaller $(\mathrm{t}$-stat $=$ -6.16). The untabulated mean (median) market capitalization of switchers is $\$ 985(\$ 145)$ million, whereas the mean (median) market capitalization of firms continuing with IFRS is $\$ 7,719$ (\$1,067) million. Therefore, switchers are primarily small and mid-cap companies according to the WFE (2013) definitions.

[Table 1 here]

Table 1 further reveals that switching firms have significantly less asset growth $(\mathrm{t}$-stat $=$ -4.42), lower return on assets $(\mathrm{t}$-stat $=-2.32)$, higher levels of goodwill $(\mathrm{t}$-stat $=1.86)$, and fewer foreign investor holdings $(\mathrm{t}$-stat $=-2.09)$ than non-switching firms. The mean and median values for leverage, stock returns, and the propensity for adopting IFRS before 2005 do not significantly differ across switching and non-switching firms.

22 According to the research design in Section 3.1.2, the control sample does not include switching firms (i.e., firms that switch from IFRS to Swiss GAAP during 2008 to 2013).

23 Our inferences do not change when we use a balanced sample of 576 (96) eligible IFRS firm-years (unique firms) with available data throughout the sample period. 
Panel $\mathrm{C}$ of Table 1 reports descriptive statistics on the change in regression variables since 2005 for the switching firms and the IFRS firm-years. For switching firms, the mean value for $\triangle I N S I D E R$ of 0.06 indicates that the average switching firm has 6 percentage points more insider ownership in the year of the announcement to switch than in 2005. However, the change in insider ownership is not significantly different across switching and non-switching firms $(\mathrm{t}$-stat $=1.37)$. While switching firms have become smaller, the size of the nonswitching firms has increased over time. Both mean and median $\triangle S I Z E$ are significantly different across switching and non-switching firms at the $1 \%$ level. The decrease in switching firms' size is consistent with a decrease in their net benefits from IFRS, in turn making a switch from IFRS to Swiss GAAP more likely.

\section{$5 \quad$ Empirical Results}

\subsection{Stated reasons for a switch in firms' press releases}

Table 2 presents the reasons that firms state in their press releases for a switch from IFRS to Swiss GAAP. Twenty-seven sample firms provide reasons for their switch, six announce a switch without providing any reasons, and one did not issue a press release about the switch. Of these 27 firms, $22(81 \%)$ mention the high or increasing complexity of IFRS accounting rules, and $18(67 \%)$ mention the high or increasing administrative costs associated with reporting under IFRS. For 15 (56\%), a switch to Swiss GAAP is legitimate, because Swiss GAAP is also based on the principle of a "true and fair view". For 13 firms (48\%), the switch will not adversely affect transparency or disclosure quality.

[Table 2 here] 
Eight firms (30\%) perceive Swiss GAAP as a solid and accredited reporting alternative that is focused on the basics, less complex, yet sufficient for capturing the complexity of SMEs. Two firms (7\%) state that detailed disclosure requirements lead to the disclosure of business secrets. Seven firms (26\%) state that they plan to apply the same accounting methods under Swiss GAAP as under IFRS if these methods are permitted under Swiss GAAP. One firm states that a switch to Swiss GAAP will not have adverse effects on its ability to obtain capital, and another firm mentions that the cost-benefit ratio is reasonable under Swiss GAAP. Taken together, the statements indicate that switching firms perceive the net benefits of IFRS to be lower than those under Swiss GAAP, largely consistent with the findings in Figure 1 from the survey on the relative perception of IFRS versus Swiss GAAP (source: Meyer 2009).

\subsection{Results of probit regressions}

Table 3 reports probit regression results for different model specifications. The explanatory power of the models increases from $23 \%$ in model (1) to $33 \%$ in model (6). Consistent with our predictions, the coefficient for INSIDER is significantly positive at the 5\% level (two-sided) throughout all model specifications. In addition, the coefficients for SIZE are significantly negative at the $1 \%$ level (two-sided). Therefore, small firms with high insider ownership are more likely to switch from IFRS to Swiss GAAP, consistent with our prediction that the net benefits of IFRS are lower for such firms.

Similar to Leuz et al. (2008), we also gauge the economic significance of our results: relative to the baseline probability of $5.1 \%$ (34 switches out of 662 observations), an increase in insider ownership from the $25^{\text {th }}$ to the $75^{\text {th }}$ percentile raises the switching probability by 2.3 percentage points, or $44.8 \%$, as indicated by the untabulated average marginal effect of 0.072 for INSIDER in model (6). The untabulated marginal effect of -0.025 for SIZE indicates that 
an increase from the 25 th to the 75 th percentile in firm size reduces switching probability towards zero. Therefore, our findings are economically meaningful.

[Table 3 here]

The negative and significant coefficients for GROWTH indicate that switching firms have less asset growth and thus fewer financing needs. In contrast to Leuz et al. (2008), who find that "going dark" firms have significantly more leverage and lower market returns, we find no significant differences in financial leverage $(L E V)$ or annualized stock returns $(R E T)$ across switching and IFRS firms.

The significantly positive coefficients for $R O A$ do not suggest that switching firms want to obfuscate poor performance by switching the accounting standard. Instead, this finding points towards the proprietary cost explanation. Therefore, to more directly proxy for potential proprietary costs of disclosure, we also use an approach similar to that of Berger and Hann (2007), calculating abnormal performance $A B N \_R O A$ as the difference between the firm's ROA and the average industry ROA. Untabulated findings reveal a significantly positive coefficient of 1.408 for $A B N \_R O A$ (z-stat $\left.=2.13\right)$, indicating that firms with higher profitability than the industry mean are more likely to switch from IFRS to Swiss GAAP. ${ }^{24}$

The negative and positive coefficients for EARLY and $G W$, respectively, are consistent with our predictions, i.e., late IFRS adopters with higher levels of goodwill are more likely to switch. However, the coefficient estimates are not significant at conventional levels. The significant negative coefficient for FOREIGN (z-stat $=-2.51)$ indicates that firms with a larger proportion of foreign investor holdings are less likely to switch. This finding is consistent with foreign investors' greater familiarity with, and demand for, IFRS.

24 The use of $A B N \_R O A$ instead of $R O A$ does neither change the magnitude nor the significance of the other explanatory variables. 


\subsection{Results of hazard model and linear probability regression}

Table 4 presents results from the Weibull hazard model (Column A) and the linear probability regression with firm fixed effects (Column B). The significant positive Weibull parameter $p$ of 5.565 is greater than 1 , indicating that the hazard (i.e., switching probability) increases over time. The coefficient estimate for INSIDER of 1.747 is significantly positive, suggesting that hazard increases with insider ownership. In other words, firms with higher insider ownership switch earlier from IFRS to Swiss GAAP. ${ }^{25}$ The hazard rates also suggest that more profitable firms with higher proportional goodwill switch earlier (ROA and $G W I L L)$, whereas large, growing firms with more foreign investors switch later (SIZE, GROWTH, and FOREIGN).

[Table 4 here]

In Column B of Table 4, the significant positive (negative) coefficient of $0.270(-0.069)$ for INSIDER (SIZE) suggests that firms with increasing (decreasing) insider ownership (size) are more likely to switch. This result is consistent with a decrease in net benefits of IFRS for these firms, rendering Swiss GAAP a more adequate reporting outlet than IFRS. Results from the linear probability regression with firm fixed effects further indicate that increasing leverage $(L E V)$ and increasing proportional goodwill $(G W I L L)$ are associated with switching from IFRS to Swiss GAAP. However, findings from the linear probability model should be

To gauge the economic magnitude of the effect, we multiply INSIDER by 100 and rerun the Weibull hazard model. We obtain a hazard rate of 1.018 for INSIDER (multiplied by 100), suggesting that every percentage point of more insider ownership increases hazard by $1.8 \%$. 
interpreted with caution, because we obtain fitted probability estimates outside the $[0,1]$ interval. $^{26}$

Taken together, the determinants tests (i.e., probit regression, hazard model, linear probability regression) indicate that the choice to switch is driven by firm-specific, timevariant net benefits of IFRS. As the findings do not suggest that poorly performing firms try to escape transparency, the switches are thus not comparable to "going dark" decisions. This finding is consistent with the majority of switching firms' press releases stating that transparency remains under Swiss GAAP via the objective of a "true and fair view".

\section{$5.4 \quad$ Reporting changes}

\subsubsection{Reporting changes after the switch}

Table 5, Panel A shows the impact of a switch on accounting disclosures, equity and net income, and audit fees. The mean number of pages of the annual report decreased by 13 pages (13\%), of which 11 pages are attributable to the notes, which decreased by $30 \%$. About two pages are attributable to a reduced outline of the accounting principles in the notes, consistent with fewer and less extensive accounting standards under Swiss GAAP than under IFRS. The total word count decreased by $18 \%$. Mean changes are statistically significant at the $1 \%$ level. While the number of positions presented in both the balance sheet and cash flow statement does not significantly change, the number of positions in the income statements decreases by

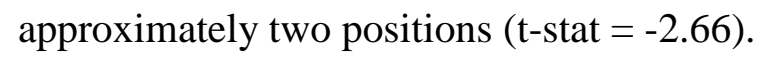

Reporting of the PSM control group is similar to that of switching firms before the switch. For example, the mean (median) number of pages in the notes is 37 (33) and 39 (39) for the switching firms and the PSM control group, respectively. However, in contrast to the

\footnotetext{
26 Specifically, 369 out of $966(38.2 \%)$ fitted probability estimates are below 0 , with a largest negative value of $-19 \%$. Therefore, econometric textbooks caution against the use of ordinary least squares estimation when the dependent variable is discrete (see, e.g., Wooldridge (2009), pp. 574-575).
} 
switching firms' substantial reduction in reporting, the PSM control group's reporting remains largely the same over time. For example, the mean number of pages in the notes to the financial statements increases by $3 \%$ for the PSM group. The (untabulated) difference-indifferences for the number of pages in the notes across switching and PSM firms is significant at the $1 \%$ level $(\mathrm{t}$-stat $=9.06)$. This finding does not suggest a generally decreasing trend in reporting but rather that the switching firms' decrease in reporting is attributable to the change in accounting standard.

Panel A of Table 5 further reveals that, before the switch, segment reporting by switching firms and the PSM control group are similar. Thirty-one out of 34 (91\%) and 32 out of 34 (94\%) switching and PSM firms, respectively, provide segment information under IFRS. However, while the segment reporting of the PSM group remains largely constant over time, the switching firms substantially reduce their segment reporting: the percentage of switching firms that provide segment reporting drops from $91 \%$ to $76 \%$, the mean number of reported segments decreases from 3 to 2 (t-stat $=-2.47$ ), and the percentage of firms disclosing segment earnings (assets and liabilities) drops from $91 \%(88 \%)$ to $38 \%$ (35\%). The results suggest that switching firms make use of the less detailed provisions for segment reporting under Swiss GAAP. These findings are also consistent with the probit results, indicating that firms switch to avoid potential proprietary costs of disclosure.

A change from IFRS to Swiss GAAP affects not only the disclosure level but also the recognition and measurement of certain items (see Section 2.2.). Table 5, Panel A shows that the mean book value of equity is $16 \%$ lower $(\mathrm{t}$-stat $=-2.95)$ under Swiss GAAP than under IFRS (restated). This difference is mainly attributable to switching firms' decision to set off goodwill against equity, consistent with their avoiding the burdensome impairment-only- 
approach required by IFRS. $^{27}$ Different accounting rules for pension accounting have a limited impact on switching firms' equity, and reported net income is not significantly different across Swiss GAAP and IFRS.

[Table 5 here]

Finally, Panel A of Table 5 shows that mean audit fees significantly decrease by $8 \%$ (tstat $=-2.24$ ), from CHF 590,000 to $542,000 .^{28}$ The decrease of $8 \%$ is equal to the abnormal IFRS-related increase in audit fees of Australian firms in the year of IFRS adoption (De George et al. 2012). Given that audit fees are positively associated with audit length and complexity, our findings indicate that annual reports under Swiss GAAP are less extensive than under IFRS.

Overall, results on the reporting consequences suggest that the switch from IFRS to Swiss GAAP is a serious change in financial reporting, not merely a change in label. In contrast to the PSM control group, the switching firms substantially reduce their disclosures (e.g., notes to financial statements or segment reporting), resulting in lower audit fees.

\subsubsection{Reporting changes since 2005}

Panel B of Table 5 presents the reporting (i.e., number of pages in the annual report, notes, and accounting principles) and audit fees for the switching firms, Swiss GAAP stayers, and PSM control group in 2005 and the year when the switch from IFRS to Swiss GAAP was announced. Switching firms' reporting significantly increases over time. In particular, the number of pages in both the notes to financial statements and the accounting principles

27 This explanation is consistent with recent efforts by the Financial Accounting Standards Board (FASB) to reduce the cost and complexity of the goodwill impairment test (FASB 2016).

28 The difference-in-differences for audit fees across switching and PSM firms is significant at the 5\% level ( $\mathrm{t}-$ stat $=2.35$ ). 
increase, on average, by $6.7(+22 \%)$ and $2.4(+36 \%)$, respectively. This result reflects the substantial changes of IFRS over time as discussed in Section 2.2.

For the PSM control group, the change in number of pages in the annual report $(+16 \%)$ and the principles of accounting $(+15 \%)$ is less pronounced than for the switching firms. ${ }^{29}$ However, the mean increase in the number of pages in the notes of $7.1(+23 \%)$ is approximately equal among PSM and switching firms, consistent with IFRS requiring more extensive disclosures since 2005. In contrast, for the Swiss GAAP stayers, the average increase in the number of pages in the notes of $1.2(+6 \%)$ is not significant, although the change in annual reporting $(+20 \%)$ is similar to that of switching and PSM firms. The insignificant increase in the notes of the Swiss GAAP stayers is consistent with less extensive accounting changes under Swiss GAAP than under IFRS.

Audit fees have significantly increased since 2005 for switching, Swiss GAAP, and PSM firms. However, the increase in audit fees of CHF 182,500 (+45\%) and CHF 194,900 (+32\%) is more pronounced for switching firms and the PSM control group, respectively, than that of Swiss GAAP stayers of CHF 38,500 (+16\%). The larger increase in audit fees for IFRS firms than for Swiss GAAP stayers is consistent with a different development in certification costs across IFRS and Swiss GAAP.

Overall, findings on reporting and audit fee changes since 2005 suggest that preparation and certification costs of IFRS have increased over time. In addition, this increase in IFRS reporting costs is not limited to switching firms. Different developments in reporting costs across IFRS and Swiss GAAP also affect the perceived net benefits of the two accounting standards. Therefore, these findings complement our previous findings, providing further explanation as to why certain firms use the option to switch from IFRS to Swiss GAAP.

\footnotetext{
29 In Panel B of Table 5, the PSM control group comprises 33 observations, because the 2005 annual report is not available for one firm. The Swiss GAAP stayers control group comprises 21 observations because of missing 2005 annual reports.
} 


\subsection{Liquidity results}

Table 6 reports the univariate DID for the proportional bid-ask spread (panel A) and the percentage of zero returns (panel B) around the switch from IFRS to Swiss GAAP. An increase in the two measures in the post-periods would be indication of a decrease in liquidity. However, the switching firms' proportional bid-ask spreads in Panel A show an opposite pattern: the mean bid-ask spread decreases after the switching announcement, after the publication of the first report under Swiss GAAP, and in the long run (i.e., two years after publication). The switching firms' mean percentage of zero returns in Panel B remains largely constant over time.

\section{[Table 6 here]}

Before the announcement, the mean bid-ask spread (percentage of zero returns) of the switching firms is higher than that of the index-matched, size- and industry-matched, and PSM control groups but similar to (lower than) that of the Swiss GAAP stayers. In Panel A (B), the mean bid-ask spreads (percentage of zero returns) of the index-matched, size- and industry matched, and PSM control groups remain largely constant (slightly increase) over time. Similar to the switching firms, the mean bid-ask spreads and percentage of zero returns of the Swiss GAAP stayers decrease over time, perhaps because of comparability benefits. ${ }^{30}$ Taken together, the univariate DID results do not indicate a substantial reduction in switching firms' liquidity after they switch to Swiss GAAP.

\footnotetext{
30 The 29 Swiss GAAP stayers likely benefit from an increase in the comparability of their reporting, because the number of firms applying Swiss GAAP substantially increases when the 34 firms switch from IFRS to Swiss GAAP.
} 
Table 7 presents findings from the multivariate DID analysis for 825 switching firmquarters and 3808 IFRS firm-quarters. In Column A, the insignificant coefficients for POST_ANNOUNCE,POST_PUBL, and POST_PUBL_8Q do not suggest an increase in bidask spreads for switching firms after the announcement to switch, after they published the first annual report under Swiss GAAP, and within the eight quarters after this publication, respectively.

[Table 7 here]

Column B of Table 7 shows a slight increase in the percentage of zero returns for switching firms after they announce the switch and after the publication of the first annual report under Swiss GAAP. However, the coefficients are not significant at conventional levels. Neither is the increase in the percentage of zero returns (about 2\%) economically large relative to their pre-publication mean of $19.1 \%$. When limiting the post-switch observations (POST_PUBL_8Q), coefficient estimates and significance levels further drop, indicating that the slight increase in percentage of zero returns might be attributable to other events that are unrelated to the switch. Taken together, univariate and multivariate liquidity analyses do not suggest a substantial decrease in firms' liquidity after the switch.

\subsection{Announcement returns}

Table 8 reports mean stock returns around the announcement to switch from IFRS to Swiss GAAP. The unadjusted raw returns of switching firms are $0.002,0.004$, and $\quad-0.003$ for the one-day, two-day, and eleven-day event window, respectively. About half of the switching firms exhibit a negative reaction: 14, 19, and 19 out of 34 firms have negative stock returns for the one-day, two-day, and eleven-day event window, respectively. Neither the raw 
returns nor the adjusted stock returns are significantly different from zero, indicating that investors perceive the switch as neither good nor bad news. ${ }^{31}$

[Table 8 here]

We acknowledge that the small sample size introduces bias in favor of accepting the null hypothesis that the switching announcement has no effect on stock returns. However, the magnitude of both the raw returns and the adjusted returns is not economically large compared to the nearly ten times larger negative market reaction when firms go dark (Leuz et al. 2008, p. 198). Therefore, we can reasonably conclude that switching firms do not experience large negative stock returns around the switching announcement.

\section{$6 \quad$ Additional analyses}

\subsection{Non-serious IFRS application?}

We are concerned that switching firms never obtained liquidity benefits around IFRS adoption because of "non-serious" IFRS application. In this case, the potential adverse effects on liquidity of a turn away from IFRS are, by definition, limited. Although Table 5 shows that switching firms reduce their disclosures—suggesting a serious change in firms' reportingwe further analyze whether switching firms' application of IFRS is sufficiently enforced (Section 6.1.1) and whether the switching firms' liquidity benefits around 2005 were indeed close to zero (Section 6.1.2).

\subsubsection{Enforcement activities}

31 Untabulated findings further reveal that the returns of early switchers (i.e., 18 firms that switch between 2008 and 2010) are neither significantly different from zero nor significantly different than the returns of the late switchers (i.e., the 16 firms that switch between 2011 and 2013). 
To the extent that the level of enforcement is lower in the Swiss than in the International Reporting Standard, our tests cannot disentangle the accounting effect from the enforcement effect of a switch. Another concern is that the switching firms are more likely to be subject to enforcement actions prior to their switch, indicating non-serious IFRS application.

To tackle potential enforcement effects on our findings, we screen all press releases that the SIX issued between January 2004 and December 2013 concerning investigations, reprimands, punitive fines, and other sanctions. We find a total of 51 investigations, 41 reprimands, 37 punitive fines, and 3 other sanctions. Figure 2 shows that enforcement activities have increased since 2005. While there were no regulatory actions in 2004, enforcement activities increase from 2005 to 2009 and remain on a moderate level from 2009 to 2013.

[Figure 2 here]

First, in both the International Reporting Standard and the Swiss Reporting Standard, 46 out of 195 firms (23.5\%) and 12 out of 48 firms (25\%), respectively, were subject to regulatory actions between 2004 and $2013 .^{32}$ In addition, $20 \%$ and $23 \%$ of the firms in both standards received a reprimand, punitive fine, or other sanction, all of which likely indicate an error in financial reporting.

Second, we perform a chi-square test (untabulated) to examine whether switching firms (before they switch) are more likely to be subject to regulatory actions than non-switchers. Nine out of $34(26.5 \%)$ switching firms and 28 out of 107 (26.2\%) non-switching firms, respectively, have been subject to regulatory action. The chi-square test statistic of 0.001 does not suggest that the difference is significant $(\mathrm{p}$-value $=97 \%)$. In addition, the likelihood of

\footnotetext{
32 We do not include the 34 switching firms in this analysis.
} 
receiving a reprimand, punitive fine, or other sanction (i.e., erroneous financial statement) does not significantly differ across the two groups (chi-square value $=0.017$, p-value $=89 \%$ ), i.e., 8 out of $34(23.5 \%)$ and 24 out of 107 (22.4\%) switching and non-switching firms, respectively.

Overall, the additional tests on enforcement activities confirm that the enforcement levels do not differ across the SIX Reporting Standards. Therefore, our setting allows us to investigate the effect of a change in accounting standard while holding other institutional factors plausibly constant. Moreover, the switching firms are not more prone to regulatory actions than non-switching firms. This finding suggests that the "accounting quality" (Dechow et al. 1996) does not substantially differ across switching and non-switching firms, thereby mitigating concerns that switching firms' application of IFRS is non-serious.

\subsubsection{Liquidity effects around IFRS adoption in 2005}

Even with strong enforcement, liquidity benefits can vary with firm-level reporting incentives (Daske et al. 2013). Therefore, we investigate liquidity effects of switching firms around IFRS adoption of the EU in 2005 . We compare quarterly proportional bid-ask spreads across the years 2004 (before IFRS) and 2006 (after IFRS) for switching and non-switching firms.

On the one hand, untabulated results reveal that liquidity benefits around 2005 are similar for switching and non-switching firms. The decrease in mean bid-ask spread of $0.8 \%$ (from $2.9 \%$ to $2.1 \%)$ for the switching firms is significant at the $1 \%$ level $(\mathrm{t}$-stat $=-3.62)$. While the decrease in mean bid-ask spread of $1.1 \%$ (from $2.0 \%$ to $0.9 \%$ ) for the non-switching firms is also significant $(\mathrm{t}-\mathrm{stat}=-2.25)$, the DID of $0.3 \%$ is insignificant $(\mathrm{t}$-stat $=0.29)$. On the other hand, the relative change in mean bid-ask spreads for switchers $(-28 \%)$ is lower than that for non-switchers $(-55 \%)$. However, the liquidity benefits of $-0.8 \%$ for the switching firms are 
substantially larger in magnitude than the average liquidity benefits of $-0.2 \%$ documented for the global sample of firms adopting IFRS in 2005 (Daske et al. 2008, p. 1106). Therefore, switching firms clearly benefit from decreasing bid-ask spreads around IFRS adoption in 2005.

Overall, we cannot entirely rule out the possibility that switching firms have different reporting incentives, and thus they might be "label adopters" according to the definition of Daske et al. (2013). We also cannot attribute the switching firms' decrease in bid-ask spreads around 2005 to an IFRS effect per se, (a) because of concurrent changes in the institutional environment (Christensen et al. 2013, Barth and Israeli 2013), and (b) because many switching and non-switching firms adopted IFRS before 2005 (see Table 1). Nonetheless, the findings from these additional tests do not confirm our main concern that switching firms never obtained liquidity benefits because of non-serious IFRS application. In addition, the results also provide some indication that the switching firms did not overestimate the net benefits of IFRS adoption.

\subsection{Other identification issues}

\subsubsection{Alternative disclosure channels}

We interpret the finding that firms substantially reduce their reporting but experience only limited adverse capital-market effects as evidence that investors in small firms with more insider ownership have a lower demand for public accounting (IFRS) information. However, a potential alternative explanation for our findings is that the switching firms compensate for the reduction in annual reporting with an increase in alternative reporting channels.

Therefore, we systematically examine whether firms change other information channels after the switch. The mean (median) number of press releases per year increases (decreases) from 14 to 15 (12 to 9). No firm changes its policy towards ad hoc publicity. The mean 
(median) number of conference calls per year remains constant at 1.1 (1.0). In addition, anecdotal evidence from listening to the conference calls of Cham Paper Group Holding and Georg Fischer does not suggest an increase in analyst questions on accounting and reporting issues. Overall, these findings do not suggest that switching firms compensate for the reduction in annual reporting disclosures with an increase in alternative information dissemination.

\subsubsection{Different trends in liquidity?}

To the extent that switching firms show a pattern of increasing liquidity (relative to the control group) before they switch, our finding that the switch has an insignificant effect on the switching firms' liquidity could be driven by different trends in liquidity. We thus have a closer look at proportional bid-ask spreads of switching and non-switching across time. Untabulated findings do not suggest a different pattern in bid-ask spreads across switching and non-switching firms. Therefore, our finding that the average liquidity of the switching firms does not decrease after the switch is unlikely to be primarily driven by different trends in liquidity.

In addition, the endogeneity concern is less pronounced as in settings in which firms voluntarily adopt IFRS (e.g., Leuz and Verrecchia 2000). Typically, firms voluntarily adopting IFRS exhibit higher growth. Thus the counterfactual in these settings is an increase in liquidity, making it difficult to attribute any ex post observed increase in liquidity to a reporting (IFRS) effect. In our setting, the switching firms exhibit less growth, as documented by the probit results in Table 3 . Therefore, the counterfactual constitutes a decrease, not an increase, in the liquidity of switching firms.

\subsubsection{Did firms switch for contractual reasons?}


Because IFRS and Swiss GAAP differ not only in the level of disclosure but also in the accounting treatment of certain items (e.g., goodwill or pension accounting), we test whether firms switch for contracting purposes. For example, if firms are close to violating a debt covenant (e.g., a contractually agreed maximum debt-to-asset ratio), they likely opt for an accounting standard that allows reporting lower debt-to-asset ratios. However, for our switching firms, it is unlikely that potential violation of debt covenants explains switching decisions, because Panel A of Table 5 documents that equity decreases, and thus the debt-toasset ratio increases. Panel A of Table 5 further shows that net income is not significantly affected by the accounting standard change.

However, return on equity (ROE) systematically increases after the switch because of the lower book value of equity and the approximately constant net income. To the extent that management is compensated based on ROE (or another income measure scaled with book value of equity), they have incentives to switch from IFRS to Swiss GAAP, thereby optimizing their performance measure. We thus check whether switching firms' compensation systematically differs from non-switching firms (i.e., the PSM control group), and in particular, whether the switching firms exhibit a higher propensity to compensate their management based on ROE (or another income measure scaled with book value of equity). Using annual reports before the year of the switch, we find that 2 out of 34 switching firms (5.9\%) use performance measures scaled with book value of equity. For the PSM control group, 3 out of $34(8.8 \%)$ firms scale the performance measures with book value of equity. Neither the switching firms nor the PSM firms change performance measures around the switch. Taken together, these additional analyses do not suggest that contractual features are a first-order explanation for the switch from IFRS to Swiss GAAP.

\section{Conclusion}


We exploit the specific features of the Swiss setting to examine determinants and consequences of a turn away from IFRS. We conduct several tests that collectively shed light on the firm-specific (time-variant) net benefits of IFRS. To obtain insights on determinants of a switch from IFRS to Swiss GAAP, we analyze firms' stated reasons (in their press releases) for a switch, and we conduct different regression analyses. To examine the consequences of the switch on financial reporting, we analyze the firms' annual reports before and after the switch. To investigate the consequences of a switch on liquidity, we conduct univariate and multivariate DID analyses. Finally, to investigate the stock market reaction at the switching announcement, we conduct an event study.

We find that the high administrative cost of IFRS reporting, the increasing complexity of IFRS, and the low perceived added value of IFRS as compared to Swiss GAAP, are reasons that firms state in press releases when announcing their switch. Results from the probit analysis show that small firms with high insider ownership and fewer foreign investor holdings are more likely to switch, consistent with lower net benefits for such firms. In addition, we find that increasing reporting costs as well as changes in firm-specific circumstances influence the net benefits of IFRS, in turn affecting the likelihood to switch. We find that, after the switch, firms substantially reduce their disclosures; for example, the number of pages in the notes to the financial statements or information on earnings per segment. We do neither find a decrease in liquidity after the switch nor negative stock market reactions around the switching announcement.

Overall, our results show that-for a certain type of firm (i.e., small firms with higher insider ownership) —IFRS might not be the optimal reporting outlet. While switching firms can substantially reduce disclosure levels (thereby saving preparation, certification, and proprietary costs), they do, on average, not experience adverse capital-market effects. 
Therefore, our findings are important for standard setters and securities regulators in shaping (future) reporting requirements for listed firms. 


\section{References}

Barth, M. E. and Israeli, D. (2013). Disentangling mandatory IFRS reporting and changes in enforcement, Journal of Accounting and Economics, 56, pp. 178-188.

Berger, B. G. and R. N. Hann (2007). Segment Profitability and the Proprietary and Agency Costs of Disclosure, The Accounting Review, 82(4), pp. 869-906.

Christensen, H. B., L. Hail, C. Leuz (2013). Mandatory IFRS Reporting and Changes in Enforcement, Journal of Accounting and Economics, 56, pp. 147-177.

Christensen, H. B., E. Lee, M. Walker and C. Zheng (2015). Incentives or Standards: What Determines Accounting Quality Changes around IFRS Adoption? European Accounting Review, 24, pp. 31-61.

Cuijpers, R. and W. Buijink (2007). Voluntary Adoption of Non-local GAAP in the European Union: A Study of Determinants and Consequences. European Accounting Review, 14(3), pp. $487-524$.

Daske, H., L. Hail, C. Leuz, and R. Verdi (2008). Mandatory IFRS reporting around the world: early evidence on the economic consequences, Journal of Accounting Research, 46(5), pp. 1085-1142.

Daske, H., L. Hail, C. Leuz, and R. Verdi (2013). Adopting a Label: Heterogeneity in the Economic Consequences around IAS/IFRS Adoptions, Journal of Accounting Research, 50(3), pp. 495-547.

Dechow, P. M., R. Sloan, and A. Sweeney (1996). Causes and consequences of earnings manipulation: An analysis of firms subject to enforcement action by the SEC. Contemporary Accounting Research, 13 (1), pp. 1-36.

De George, E. T., C. B. Ferguson, and N. A. Spear (2012). How Much Does IFRS Cost? IFRS Adoption and Audit Fees, The Accounting Review, 88(2), pp. 429-462.

Deloitte (2014). Financial reporting by listed companies: Spotlight on Swiss trends, https://www2.deloitte.com/content/dam/Deloitte/ch/Documents/audit/ch-en-audit-ifrssurvey-october-2014.pdf.

Diamond, D., and R. Verrecchia R. (1991). Disclosure, Liquidity and the Cost of Capital. Journal of Finance, 46, pp. 1325-1359.

Dumontier, P., and B. Raffournier (1998). Why firms comply voluntarily with IAS: an empirical analysis with Swiss Data. Journal of International Financial Management \& Accounting 9(3), pp. 216-245. 
Eng, L.L., and Y. T. Mak (2003). Corporate governance and voluntary disclosure, Journal of Accounting and Public Policy, 22(4), pp. 325-345.

Ernst \& Young (2013). Avoiding disclosure overload in financial statements, IFRS Outlook, March 2013.

Financial Accounting Standards Board (FASB) (2016). Accounting for Goodwill Impairment. Project Update, March 2016.

Foundation for accounting and reporting recommendations (FER) (2012). Accounting and Reporting Recommendations 2012/13, Zurich.

Foundation for accounting and reporting recommendations (FER) (2014). Rechnungslegung kleiner und mittelgrosser Unternehmen in der Schweiz, https://www.fer.ch/content/uploads/2016/11/Rechnungslegung_kleiner_und_mitteler_Unte rnehmen_2014.pdf

Hail, L. (2002). The impact of voluntary corporate disclosures on the ex-ante cost of capital for Swiss firms. European Accounting Review 11(4), pp. 741-773

Hail, L., C. Leuz, and P. Wysocki (2010). Global Accounting Convergence and the Potential Adoption of IFRS by the U.S. (Part I): Conceptual Underpinnings and Economic Analysis, Accounting Horizons, 24(3), pp. 355-394.

Hitz, J. M. and S. Müller-Bloch (2014). Why Do Firms Go Grey? Evidence on the Costs of IFRS Compliance and Enforcement, working paper, University of Göttingen.

Hoogervorst (2015). Switzerland and IFRS, IASB Speech, Zurich, Switzerland.

International Accounting Standards Board (IASB) (2009). Framework for the Preparation and the Presentation of Financial Statements, London, U.K.: IASB.

International Accounting Standards Board (IASB) (2011). Conceptual Framework for Financial Reporting, London, U.K.: IASB.

International Accounting Standards Board (IASB) (2013a). Joint effort needed to tackle disclosure problem. IASB Press Release, January 2013.

International Accounting Standards Board (IASB) (2013b). Discussion Forum-Financial Reporting Disclosure. Feedback Statement, May 2013.

Jensen, M. C. and W. H. Meckling (1976). Theory of the Firm: Managerial Behavior, Agency Costs and Ownership Structure, Journal of Financial Economics, 3(4), pp. 305-360.

Johnstone, D. J. (2015). Information and the Cost of Capital in a Mean-Variance Efficient Market, Journal of Business Finance \& Accounting, 42(1-2), pp. 79-100. 
Kiefer, N. M. (1988). Economic duration data and hazard functions. Journal of Economic Literature 26 (June): 646-679.

Landsman, W. R., E. L. Maydew, and J. R. Thornock (2012). The information content of annual earnings announcements and mandatory adoption of IFRS. Journal of Accounting and Economics, 53, pp. 34-54.

Leuz, C., A. Triantis, and T. Y. Wang (2008). Why do firms go dark? Causes and economic consequences of voluntary SEC deregistrations, Journal of Accounting and Economics, 45, pp. 181-208.

Leuz, C. and R. E. Verrecchia (2000). The economic consequences of increased disclosure, Journal of Accounting Research, 38 (supplement), pp. 91-124.

Li, S. (2010). Does mandatory adoption of International Financial Reporting Standards in the European Union reduce the cost of equity capital? The Accounting Review, 85(2), pp. 607636.

Meek, G.K., C. B. Roberts, and S. J. Gray (1995). Factors influencing voluntary annual report disclosures by U.S., U.K. and Continental European multinational corporations, Journal of International Business Studies, 26(3), pp. 555-572.

Meyer, C. (2009). Rechnungslegung kleiner und mittelgrosser Unternehmen in der Schweiz, http://www.business.uzh.ch/dam/jcr:00000000-7178-3884-ffffffffa8da51b7/Rechnungslegung_kleiner_und_mittelgrosser_Unternehmen_in_der_Schweiz .pdf

Petersen, T. (1991). The statistical analysis of event histories. Sociological Methods and Research 19 (February): 270-323.

Petersen, M. A. 2009. Estimating standard errors in finance panel data sets: Comparing approaches. Review of Financial Studies 22 (1): 435-480.

Ruland, W., S. Tung, and N. George (1990). Factors associated with the disclosure of managers' forecasts. The Accounting Review, 63(3), pp. 710-721.

SIX Swiss exchange (SIX) (2015a). SIX Listing Rules, https://www.six-exchangeregulation.com/dam/downloads/regulation/admission-manual/listing-rules/03_01-

LR_en.pdf

SIX Swiss exchange (SIX) (2015b). Directive on Financial Reporting, https://www.sixexchange-regulation.com/dam/downloads/regulation/admission-manual/directives/06_14DFR_en.pdf 
Wagenhofer, A. (1990). Voluntary disclosure with a strategic opponent, Journal of Accounting and Economics, 12, pp. 341-364.

Wooldridge, J.M. (2009). Introductory Econometrics: A Modern Approach, 4th Edition, Massachusetts: MIT Press.

World Federation of Exchanges (WFE) (2013). WFE Market Segmentation Survey, http://world-exchanges.org/reports/studies-and-surveys 
Figure 1. Survey results on the perception of Swiss GAAP and IFRS (source: Meyer 2009)

a) Respondents: non-listed Swiss SMEs

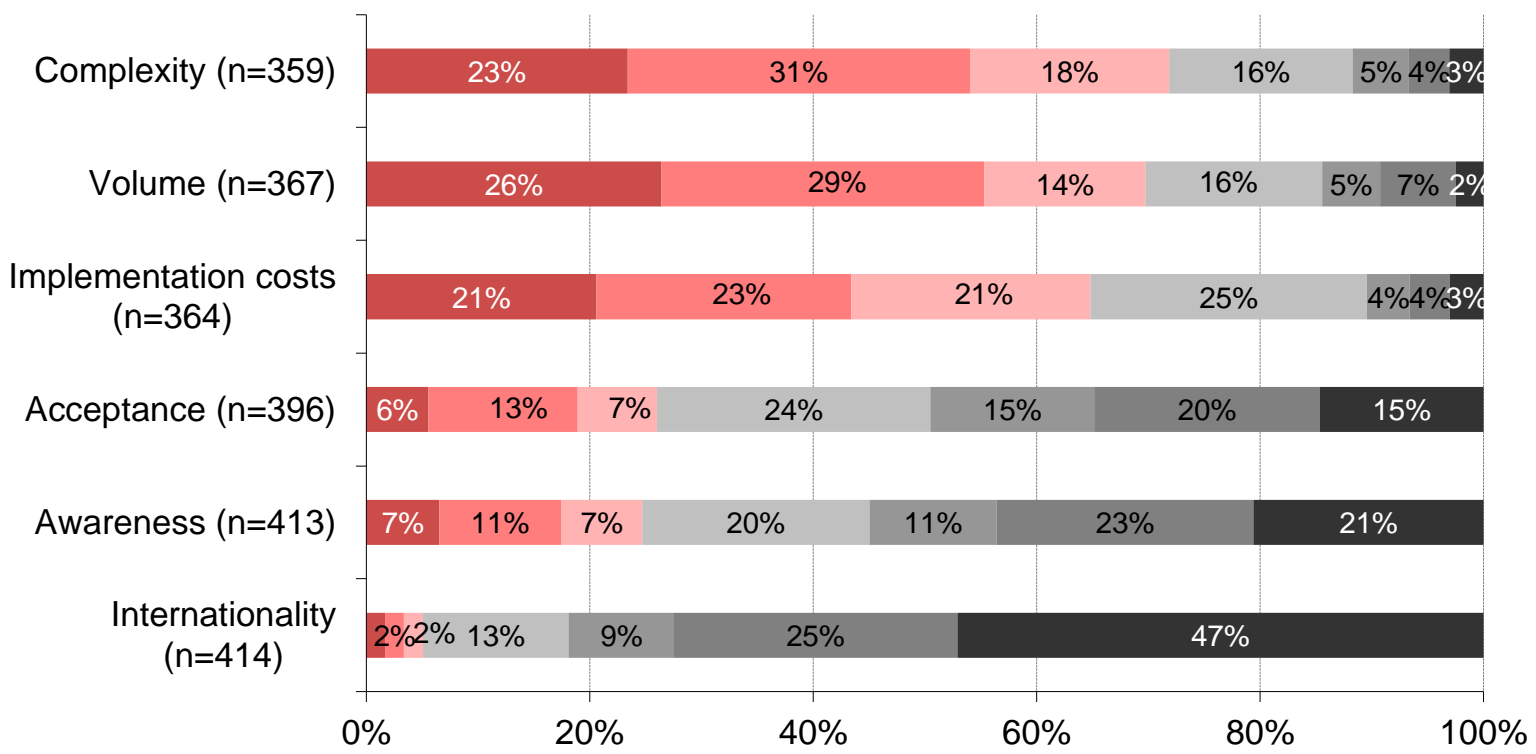

$\square++$ : Advantage of Swiss GAAP $\quad++\quad++0 \quad \square+\square++\quad \square+++$ : Advantage of IFRS for SMEs

b) Respondents: listed Swiss SMEs

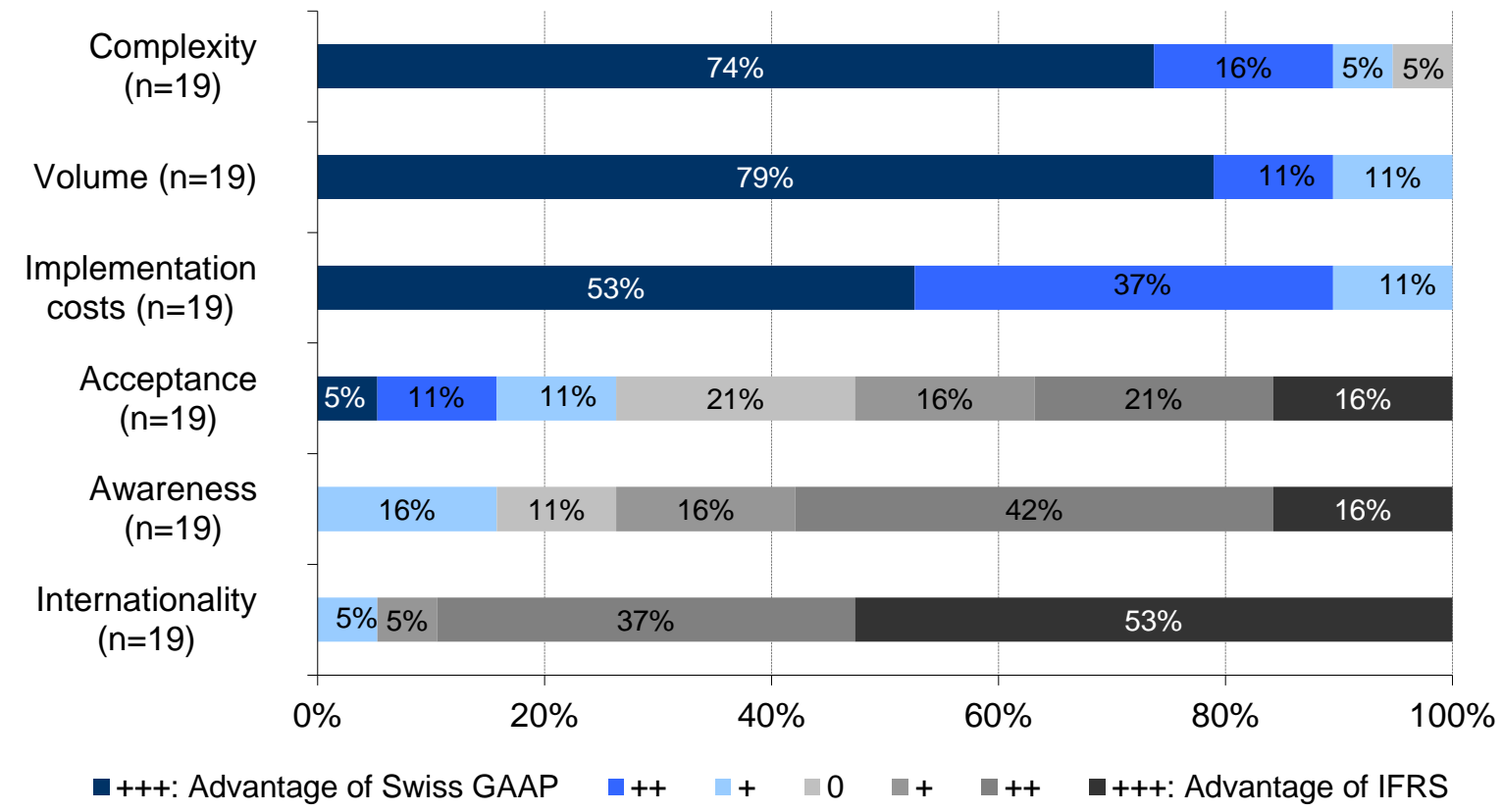


Figure 2. Enforcement activities in Switzerland from 2004 to 2013

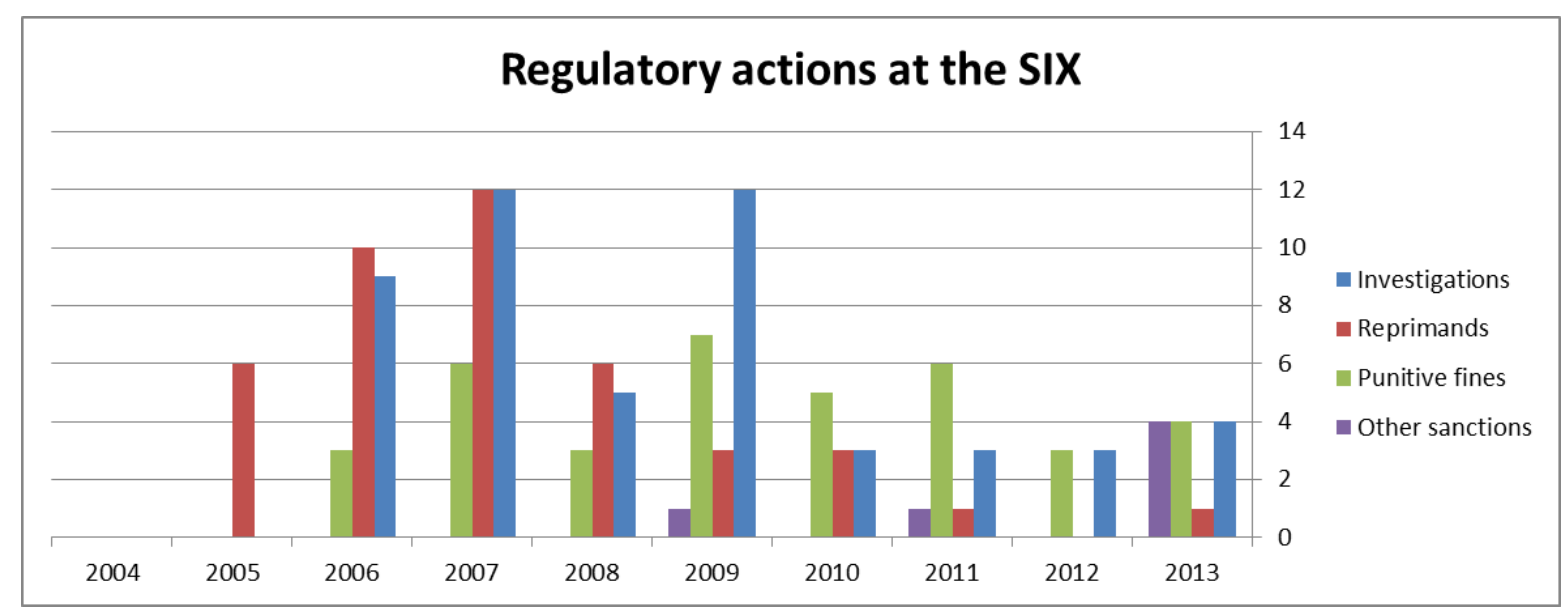


Table 1. Descriptive statistics

Panel A: Switching firms $($ SWITCH $=1)$

\begin{tabular}{lllllllll} 
Variable & N & Mean & Min & p25 & Median & p75 & Max & Std. dev. \\
\hline INSIDER & 34 & $0.35^{* * *}$ & 0.00 & 0.00 & $0.32^{* * *}$ & 0.61 & 0.81 & 0.29 \\
SIZE & 34 & $18.94^{* * *}$ & 12.73 & 18.09 & $19.35^{* * *}$ & 19.94 & 23.07 & 1.88 \\
GROWTH & 34 & $-0.10^{* * *}$ & -0.85 & -0.16 & $-0.05^{* * *}$ & 0.01 & 0.10 & 0.20 \\
LEV & 34 & 0.59 & 0.18 & 0.34 & 0.55 & 0.70 & 1.91 & 0.34 \\
ROA & 34 & $-0.01 * *$ & -0.78 & -0.04 & $0.03 * *$ & 0.08 & 0.22 & 0.17 \\
RET & 34 & -0.06 & -0.60 & -0.26 & -0.03 & 0.15 & 0.50 & 0.31 \\
GWILL & 34 & $0.12^{*}$ & 0.00 & 0.00 & 0.04 & 0.15 & 0.89 & 0.20 \\
EARLY & 34 & 0.59 & 0.00 & 0.00 & 1.00 & 1.00 & 1.00 & 0.50 \\
FOREIGN & 34 & $0.03 * *$ & 0.00 & 0.00 & $0.00 * *$ & 0.06 & 0.21 & 0.06 \\
\hline
\end{tabular}

Panel B: IFRS firm-years $($ SWITCH $=0)$

\begin{tabular}{lllllllll} 
Variable & N & Mean & Min & p25 & Median & p75 & Max & Std. dev. \\
\hline INSIDER & 628 & 0.17 & 0.00 & 0.00 & 0.00 & 0.31 & 0.88 & 0.23 \\
SIZE & 628 & 21.16 & 15.44 & 19.73 & 21.09 & 22.10 & 28.45 & 2.05 \\
GROWTH & 628 & 0.04 & -0.75 & -0.04 & 0.03 & 0.10 & 2.10 & 0.18 \\
LEV & 628 & 0.55 & 0.05 & 0.39 & 0.56 & 0.68 & 1.38 & 0.21 \\
ROA & 628 & 0.04 & -0.76 & 0.01 & 0.04 & 0.09 & 1.18 & 0.13 \\
RET & 628 & 0.01 & -0.96 & -0.27 & -0.01 & 0.23 & 1.91 & 0.42 \\
GWILL & 628 & 0.08 & 0.00 & 0.00 & 0.04 & 0.13 & 0.93 & 0.11 \\
EARLY & 628 & 0.67 & 0.00 & 0.00 & 1.00 & 1.00 & 1.00 & 0.47 \\
FOREIGN & 628 & 0.10 & 0.00 & 0.00 & 0.00 & 0.10 & 0.83 & 0.19
\end{tabular}

(continued on next page) 
Table 1 (continued)

Panel C: Change in firm characteristics since 2005

\begin{tabular}{|c|c|c|c|c|c|c|c|c|}
\hline Variable & $\mathbf{N}$ & Mean & Min & p25 & Median & p75 & Max & Std. \\
\hline \multicolumn{9}{|c|}{ Switching firms } \\
\hline$\triangle I N S I D E R$ & 34 & 0.06 & -0.36 & -0.03 & 0.00 & 0.05 & 0.80 & 0.26 \\
\hline$\triangle S I Z E$ & 34 & $-0.14 * * *$ & -5.07 & -0.41 & $-0.06 * * *$ & 0.20 & 3.49 & 1.43 \\
\hline$\triangle G R O W T H$ & 34 & -0.15 & -1.05 & -0.16 & $-0.10 * * *$ & 0.01 & 0.18 & 0.26 \\
\hline$\triangle L E V$ & 34 & 0.00 & -0.79 & -0.11 & $0.03 *$ & 0.17 & 0.67 & 0.25 \\
\hline$\triangle R O A$ & 34 & -0.03 & -0.26 & -0.09 & $-0.03 * *$ & 0.01 & 0.43 & 0.12 \\
\hline$\triangle R E T$ & 34 & -0.22 & -1.51 & -0.56 & -0.13 & 0.09 & 0.63 & 0.46 \\
\hline$\triangle G W I L L$ & 34 & 0.05 & -0.17 & -0.02 & 0.00 & 0.05 & 0.88 & 0.17 \\
\hline$\triangle E A R L Y$ & 34 & 0.00 & 0.00 & 0.00 & 0.00 & 0.00 & 0.00 & 0.00 \\
\hline$\triangle F O R E I G N$ & 34 & -0.01 & -0.34 & 0.00 & 0.00 & 0.00 & 0.21 & \\
\hline
\end{tabular}

\section{IFRS firm-years}

$\begin{array}{lllllllll}\triangle I N S I D E R & 438 & 0.02 & -0.70 & -0.01 & 0.00 & 0.01 & 0.80 & 0.18 \\ \triangle S I Z E & 438 & 0.24 & -2.46 & -0.01 & 0.27 & 0.58 & 2.06 & 0.61 \\ \triangle G R O W T H & 438 & -0.09 & -4.45 & -0.13 & 0.01 & 0.10 & 0.88 & 0.59 \\ \triangle L E V & 438 & -0.03 & -0.77 & -0.11 & -0.03 & 0.05 & 1.29 & 0.19 \\ \triangle R O A & 438 & -0.04 & -4.62 & -0.03 & 0.00 & 0.04 & 1.01 & 0.55 \\ \triangle R E T & 438 & -0.12 & -2.37 & -0.42 & -0.11 & 0.16 & 1.73 & 0.53 \\ \triangle G W I L L & 438 & 0.01 & -0.90 & -0.01 & 0.00 & 0.05 & 0.93 & 0.16 \\ \triangle E \text { EARLY } & 438 & 0.00 & 0.00 & 0.00 & 0.00 & 0.00 & 0.00 & 0.00 \\ \triangle F O R E I G N & 438 & 0.02 & -0.36 & -0.02 & 0.00 & 0.05 & 0.83 & 0.17\end{array}$

This table reports descriptive statistics of the regression variables for firms that switch from IFRS to Swiss GAAP in the year of the announcement (Panel A) and firms that continue reporting under IFRS (Panel B). SWITCH is an indicator variable that equals 1 for firms that switch from IFRS to Swiss GAAP in the year of the announcement, is missing for switching firms in the years before and after the year of the switch, and equals 0 for firms applying IFRS throughout the sample period from 2008 to 2013. INSIDER is the percentage of strategic share holdings of 5\% or more held by employees or by individual investors. SIZE is the natural logarithm of the total assets. GROWTH is the average growth of the total assets for the preceding two years. $L E V$ is the debt-to-assets ratio. $R O A$ is the ratio of net income (excluding potential accounting effects of the switch on net income) to total assets in the year of the announcement. RET is the annual stock market return of the firm's common equity in the year of the announcement. EARLY is an indicator variable that equals 1 if the firm has adopted IFRS prior to 2005. GWILL is the goodwill over total assets. FOREIGN is the percentage of strategic share holdings of $5 \%$ or more held in a country outside that of the issuer. All variables are measured at the beginning of the year except for GROWTH, ROA, and RET.

Panel $\mathrm{C}$ reports the change in regression variables since 2005 for switching and non-switching firms. $\triangle I N S I D E R$ is INSIDER measured at the beginning of the year of the announcement to switch minus INSIDER measured at the beginning of 2005 . The other changes $(\Delta)$ in regression variables are analogously calculated.

$* * *, * *$, and $*$ indicate that the means (medians) are significantly different at the $1 \%, 5 \%$, and $10 \%$ levels, respectively, using a two-tailed $t$-test (Mann-Whitney-Wilcoxon test). 
Table 2. Stated reasons for a switch from IFRS to Swiss GAAP in press releases

\begin{tabular}{llll}
\hline Stated reasons in press releases & & $\#$ & $\%$ \\
\cline { 1 - 3 } Main reasons & & & \\
Complexity of IFRS is high or increasing. & 22 & $81 \%$ \\
Administrative costs associated with reporting under IFRS are high or increasing. & 18 & $67 \%$ \\
Swiss GAAP is based on the principle of "true and fair view". & 15 & $56 \%$ \\
Transparency or disclosure quality in IFRS reports is comparable to reports according to Swiss GAAP. & 13 & $48 \%$
\end{tabular}

\section{Other reasons}

Swis s GAAP is a solid and accredited accounting standard.

The same methods used under IFRS are going to be used under Swis s GAP if permitted.

Higher complexity and costs expected because of admission of IFRS for U.S. companies.

Rules of Swis s GAAP are sufficient or better for capturing the complexity of the firm's business.

IFRS has too many disclosure requirements.

Swiss GAAP focuses on the basics.

IFRS has converged too much to U.S. GAAP in recent years.

Detailed disclosure requirements of IFRS lead to disclosures of business secrets.

Costs of Swis sAAP reporting are acceptable for medium-sized companies.

A switch from IFRS to Swiss GAAP implies only small accounting changes.

Swiss GAAP is a comprehensible body of accounting rules.

$\begin{array}{ll}1 & 4 \%\end{array}$

A switch from IFRS to Swiss GAAP will not have adverse effects on the firm's ability to obtain capital. $1 \%$

IFRS and Swis s GAAP have the same conceptual framework. $4 \%$

Swiss GAAP is adequate for international Swiss companies. $4 \%$

Application of IFRS would lead to biased financial reporting. $\quad 4 \%$

Cost-benefit ratio is reasonable under Swiss GAAP. $4 \%$

This table reports firms' stated reasons for switching from IFRS to Swiss GAAP in their press releases. The second column reports the number of firms that mention this reason. The sample consists of 34 firms that announced the switch between 2008 and 2013 . Of these 34 firms, seven have either no press release related to the switch or do not mention any reasons for the switch in their press release. For the percentages, only the 27 firms that state reasons for the switch are considered. 
Table 3. Probit regression on the determinants of a switch from IFRS to Swiss GAAP

Dependent variable: $S$ WITCH

Variables $\quad$ Predicted sign
Coefficient estimates, z-stats

(3) (4) (5)

(6)

\begin{tabular}{|c|c|c|c|c|c|c|c|}
\hline INSIDER & + & $\begin{array}{l}0.934 * * \\
(2.24)\end{array}$ & $\begin{array}{l}1.020 * * \\
(2.12)\end{array}$ & $\begin{array}{l}1.032^{* *} \\
(2.15)\end{array}$ & $\begin{array}{l}1.011 * * \\
(2.13)\end{array}$ & $\begin{array}{l}1.073^{* *} \\
(2.22)\end{array}$ & $\begin{array}{l}0.978^{* *} \\
(2.01)\end{array}$ \\
\hline SIZE & - & $\begin{array}{l}-0.304 * * * \\
(-3.77)\end{array}$ & $\begin{array}{l}-0.299 * * * \\
(-3.49)\end{array}$ & $\begin{array}{l}-0.327 * * * \\
(-3.74)\end{array}$ & $\begin{array}{l}-0.347 * * * \\
(-3.76)\end{array}$ & $\begin{array}{l}-0.334 * * * \\
(-3.73)\end{array}$ & $\begin{array}{l}-0.340 * * * \\
(-3.76)\end{array}$ \\
\hline GROWTH & - & $\begin{array}{l}-2.089 * * * \\
(-3.65)\end{array}$ & $\begin{array}{l}-2.499 * * * \\
(-4.18)\end{array}$ & $\begin{array}{l}-2.649 * * * \\
(-4.12)\end{array}$ & $\begin{array}{l}-2.367 * * * \\
(-3.42)\end{array}$ & $\begin{array}{l}-2.529 * * * \\
(-3.67)\end{array}$ & $\begin{array}{l}-2.525 * * * \\
(-3.72)\end{array}$ \\
\hline$L E V$ & $?$ & $\begin{array}{l}0.362 \\
(0.71)\end{array}$ & $\begin{array}{l}0.562 \\
(0.98)\end{array}$ & $\begin{array}{l}0.571 \\
(0.97)\end{array}$ & $\begin{array}{l}0.585 \\
(0.99)\end{array}$ & $\begin{array}{l}0.578 \\
(1.00)\end{array}$ & $\begin{array}{l}0.638 \\
(1.07)\end{array}$ \\
\hline$R O A$ & $?$ & $\begin{array}{l}1.601 * * \\
(2.45)\end{array}$ & $\begin{array}{l}1.900 * * * \\
(2.70)\end{array}$ & $\begin{array}{l}2.277 * * * \\
(3.25)\end{array}$ & $\begin{array}{l}2.058^{* * *} * \\
(2.92)\end{array}$ & $\begin{array}{l}2.182 * * * \\
(3.12)\end{array}$ & $\begin{array}{l}2.158^{* * * *} \\
(3.06)\end{array}$ \\
\hline$R E T$ & - & $\begin{array}{l}-0.209 \\
(-1.26)\end{array}$ & $\begin{array}{l}-0.251 \\
(-1.50)\end{array}$ & $\begin{array}{l}-0.427 \\
(-1.61)\end{array}$ & $\begin{array}{l}-0.368 \\
(-1.46)\end{array}$ & $\begin{array}{l}-0.358 \\
(-1.48)\end{array}$ & $\begin{array}{l}-0.372 \\
(-1.45)\end{array}$ \\
\hline GWILL & + & & & & $\begin{array}{l}0.888 \\
(1.01)\end{array}$ & $\begin{array}{l}0.885 \\
(1.01)\end{array}$ & $\begin{array}{l}0.667 \\
(0.76)\end{array}$ \\
\hline EARLY & - & & & & & $\begin{array}{l}-0.281 \\
(-1.04)\end{array}$ & $\begin{array}{l}-0.313 \\
(-1.18)\end{array}$ \\
\hline FOREIGN & - & & & & & & $\begin{array}{l}-1.942 * * \\
(-2.48)\end{array}$ \\
\hline Constant & $?$ & $\begin{array}{l}3.987 * * * \\
(2.65)\end{array}$ & $\begin{array}{l}4.068^{* *} \\
(2.28)\end{array}$ & $\begin{array}{l}3.984 * * \\
(2.07)\end{array}$ & $\begin{array}{l}4.361 * * \\
(2.19)\end{array}$ & $\begin{array}{l}4.195^{* *} \\
(2.16)\end{array}$ & $\begin{array}{l}4.373^{* *} \\
(2.23)\end{array}$ \\
\hline Year fixed effects & & No & No & Yes & Yes & Yes & Yes \\
\hline Industry fixed effects & & No & Yes & Yes & Yes & Yes & Yes \\
\hline Pseudo R2 & & $23.0 \%$ & $27.1 \%$ & $30.6 \%$ & $31.0 \%$ & $31.6 \%$ & $33.0 \%$ \\
\hline Observations & & 662 & 662 & 662 & 662 & 662 & 662 \\
\hline
\end{tabular}

The table reports probit coefficient estimates and, in parentheses, z-statistics based on heteroskedasticity-robust standard errors clustered by firm (Petersen, 2009). The dependent variable, SWITCH, is an indicator variable that equals 1 for firms that switch from IFRS to Swiss GAAP in the year of the announcement, is missing for switching firms in the years before and after the year of the switch, and equals 0 for firms applying IFRS throughout the sample period from 2008 to 2013. Model (1) does not include year and industry fixed effects, Model (2) includes industry fixed effects, and Models (3) to (6) include both year and industry fixed effects. See Table 1 for the definition of the explanatory variables. $* * * * *$, and $*$ indicate statistical significance at the $1 \%, 5 \%$, and $10 \%$ levels (two-tailed). 
Table 4. Hazard model and linear probability regression on the switching determinants

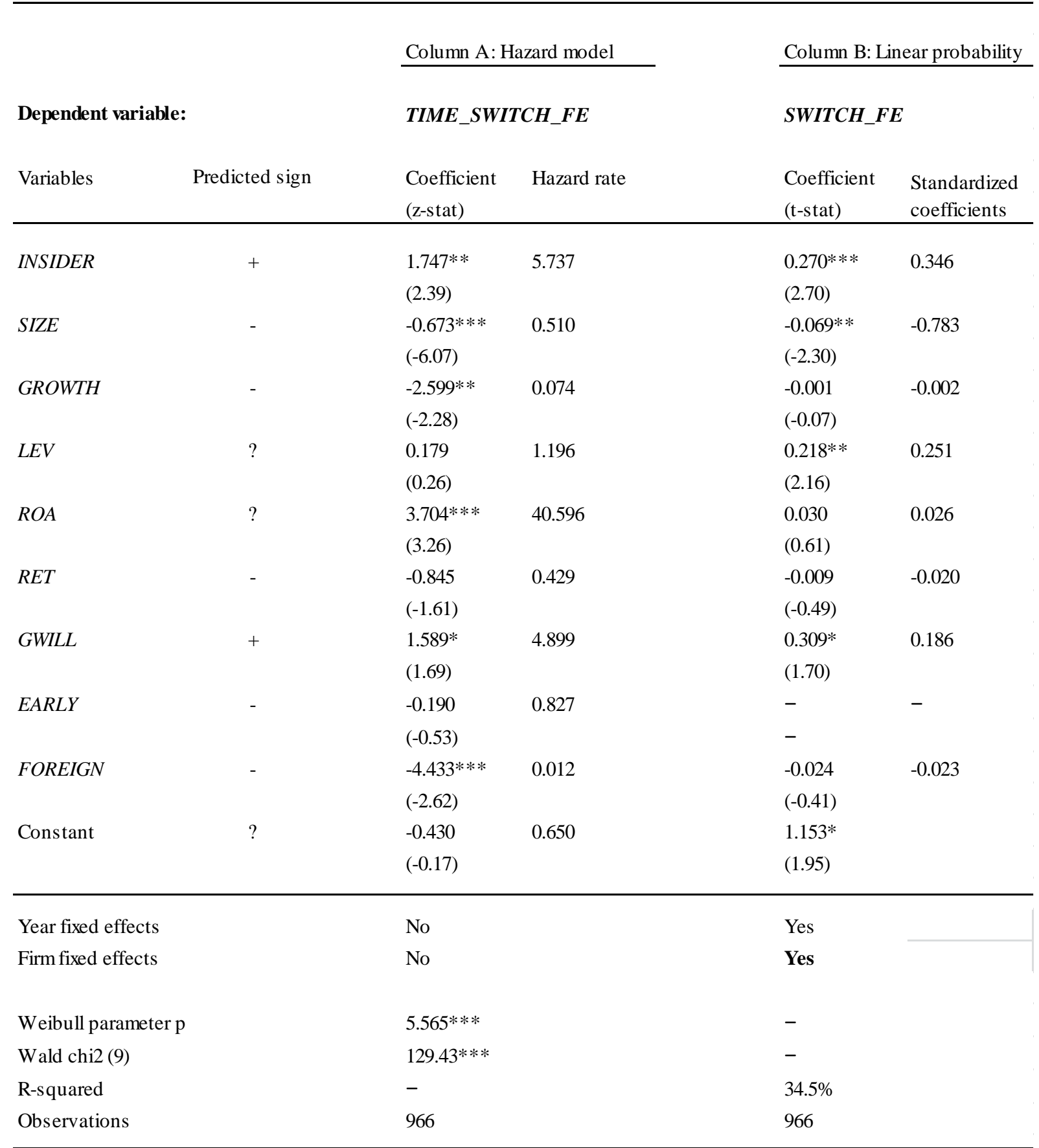

Column A reports Weibull hazard model coeffcient estimates and, in parentheses, z-statistics based on heteroskedasticity-robust standard errors (Petersen, 2009). For switching firms, SWITCH_FE equals 1 in the year of the announcement to switch, 0 in the years prior the switch, and is missing in the years after the switch. For non-switching firms, SWITCH_FE equals 0 throughout the sample period (i.e., 2006 until 2013). TIME is the time at risk from 2006 (value = 1) until 2013 (value = 8). The dependent variable TIME_SWITCH_FE is a combination of TIME and whether or not the event (switch from IFRS to Swiss GAAP) occurs.

Column B reports OLS coefficient estimates of a linear probability model with firm fixed effects and, in parentheses, tstatistics based on heteroskedasticity-robust standard errors clustered by firm (Petersen, 2009).

See Table 1 for the definition of the explanatory variables. ***,**, and * indicate statistical significance at the $1 \%$, $5 \%$, and $10 \%$ levels (two-tailed). 
Table 5. Reporting changes

\begin{tabular}{|c|c|c|c|c|c|c|c|c|c|c|c|c|c|}
\hline \multirow{3}{*}{ Annual reporting: Switchers } & \multirow[b]{2}{*}{$\mathrm{N}$} & \multicolumn{5}{|c|}{ IFRS } & \multicolumn{5}{|c|}{ Swiss GAAP } & \multicolumn{2}{|c|}{ Mean differences } \\
\hline & & Mean & $\underline{\text { Std. dev. }}$ & $\underline{\mathrm{p} 25}$ & Median & $\underline{\mathrm{p} 75}$ & $\underline{\text { Mean }}$ & Std. dev. & $\underline{\mathrm{p} 25}$ & Median & $\underline{\mathrm{p} 75}$ & (t-stat) & in $\%$ \\
\hline & & & & & & & & & & & & & \\
\hline Number of pages in the annual report & 34 & 103 & 39 & 76 & 98 & 120 & 90 & 36 & 66 & 85 & 105 & $\begin{array}{l}-13.1 * * * \\
(-6.75)\end{array}$ & $-13 \%$ \\
\hline Number of pages in the notes & 34 & 37 & 14 & 27 & 33 & 46 & 26 & 10 & 18 & 24 & 31 & $\begin{array}{l}-11.1 * * * \\
(-8.86)\end{array}$ & $-30 \%$ \\
\hline Number of pages on principles of accounting & 34 & 9 & 3 & 7 & 9 & 10 & 7 & 3 & 6 & 7 & 10 & $\begin{array}{l}-1.5 \text { *** } \\
(-2.95)\end{array}$ & $-16 \%$ \\
\hline Number of words in the annual report (in 1000 s) & 34 & 31 & 15 & 22 & 26 & 36 & 25 & 13 & 18 & 22 & 28 & $\begin{array}{l}-5.4 * * * \\
(-3.92)\end{array}$ & $-18 \%$ \\
\hline Number of positions in the balance sheet & 34 & 33 & 5 & 31 & 34 & 37 & 33 & 5 & 29 & 34 & 36 & $\begin{array}{c}0.0 \\
(0.11)\end{array}$ & $+0 \%$ \\
\hline Number of positions in the income statement & 34 & 21 & 4 & 18 & 21 & 23 & 20 & 5 & 17 & 19 & 22 & $\begin{array}{l}-1.8 * * \\
(-2.66)\end{array}$ & $-9 \%$ \\
\hline Number of positions in the cash flow statement & 34 & 33 & 6 & 29 & 32 & 37 & 33 & 6 & 31 & 33 & 36 & $\begin{array}{c}0.5 \\
(0.52)\end{array}$ & $+2 \%$ \\
\hline Annual Reporting: PSM control group & & & & IF & & & & & & & & & \\
\hline Number of pages in the annual report & 34 & 112 & 37 & 86 & 100 & 132 & 113 & 37 & 88 & 101 & 134 & $\begin{array}{c}0.3 \\
(0.13)\end{array}$ & $+0 \%$ \\
\hline Number of pages in the notes & 34 & 39 & 11 & 29 & 39 & 47 & 40 & 12 & 29 & 40 & 48 & $\begin{array}{c}1.1 \\
(1.32)\end{array}$ & $+3 \%$ \\
\hline Number of pages on principles of accounting & 34 & 9 & 3 & 7 & 9 & 11 & 9 & 3 & 7 & 9 & 12 & 0.2 & $+3 \%$ \\
\hline Segment reporting: Switchers & & & & IF & & & & & Swiss & & & & \\
\hline Number of segments in the annual report & 31 & 3 & 2 & 3 & 5 & 2 & 2 & 2 & 2 & 3 & 1 & $\begin{array}{l}-1.0 * * \\
(-2.47)\end{array}$ & $-30 \%$ \\
\hline Segment reporting (in \%) & & $91 \%$ & & & & & $76 \%$ & & & & & & $-16 \%$ \\
\hline Segment earnings (e.g., EBIT) disclosed (in \%) & & $91 \%$ & & & & & $38 \%$ & & & & & & $-58 \%$ \\
\hline Segment assets and liabilities disclosed (in \%) & & $88 \%$ & & & & & $35 \%$ & & & & & & $-60 \%$ \\
\hline
\end{tabular}




\section{Table 5 (continued)}

\begin{tabular}{|c|c|c|c|c|c|c|c|c|c|c|c|c|c|}
\hline \multirow[b]{3}{*}{ Segment reporting: PSM control group } & \multirow[b]{2}{*}{$\mathrm{N}$} & \multicolumn{5}{|c|}{ IFRS } & \multicolumn{5}{|c|}{ IFRS } & \multicolumn{2}{|c|}{ Mean differences } \\
\hline & & Mean & Std. dev. & $\underline{\mathrm{p} 25}$ & Median & $\underline{\mathrm{p} 75}$ & $\underline{\text { Mean }}$ & Std. dev. & $\mathrm{p} 25$ & Median & $\underline{\mathrm{p} 75}$ & (t-stat) & in $\%$ \\
\hline & & & & & & & & & & & & & \\
\hline Number of segments in the annual report & 32 & 3 & 2 & 3 & 4 & 1 & 3 & 2 & 3 & 4 & 1 & $\begin{array}{c}-0.0 \\
(0.00)\end{array}$ & $-1 \%$ \\
\hline Segment reporting (in \%) & & $\mathbf{9 4 \%}$ & & & & & $\mathbf{9 4 \%}$ & & & & & & $+0 \%$ \\
\hline Segment earnings (e.g., EBIT) disclosed (in \%) & & $94 \%$ & & & & & $82 \%$ & & & & & & $-13 \%$ \\
\hline Segment assets and liabilities disclosed (in \%) & & $85 \%$ & & & & & $79 \%$ & & & & & & $-7 \%$ \\
\hline Equity and net income (in CHF millions) & & & & IFRS & & & & & Swiss & & & & \\
\hline Shareholders' equity & 34 & 490 & 1566 & 39 & 120 & 313 & 411 & 1436 & 35 & 81 & 216 & $-79 * * *$ & $-16 \%$ \\
\hline Goodwill set off against equity & & & & & & & -79 & 145 & -83 & -10 & 0 & $(-2.95)$ & \\
\hline Pension accounting & & & & & & & 1 & 20 & 0 & 0 & 3 & & \\
\hline Tax and other effects & & & & & & & -2 & 11 & -3 & 0 & 0 & & \\
\hline Net income & 34 & 60 & 273 & -3 & 4 & 22 & 62 & 273 & -3 & 5 & 23 & 1 & $+2 \%$ \\
\hline Goodwill set off against equity & & & & & & & 1 & 3 & 0 & 0 & 0 & $(1.25)$ & \\
\hline Pension accounting & & & & & & & -2 & 10 & 0 & 0 & 0 & & \\
\hline Tax and other effects & & & & & & & 1 & 4 & 0 & 0 & 0 & & \\
\hline Audit: Switchers (in CHF thousands) & & & & IFRS & & & & & Swiss & & & & \\
\hline Audit fees & 34 & $\mathbf{5 9 0}$ & 857 & 164 & 319 & 521 & 542 & 902 & 148 & 263 & 516 & $\begin{array}{l}-48 \text { ** } \\
(-2.24)\end{array}$ & $-8 \%$ \\
\hline Additional fees & 34 & 153 & 340 & 9 & 68 & 176 & 173 & 291 & 17 & 67 & 183 & +20 & $+13 \%$ \\
\hline Audit: PSM control group (in CHF thousands) & & & & IFRS & & & & & IF & & & & \\
\hline Audit fees & 34 & 807 & 996 & 259 & 541 & $1^{\prime} 031$ & 774 & 792 & 287 & 519 & $1^{\prime} 039$ & $\begin{array}{c}-34 \\
(-0.76)\end{array}$ & $-4 \%$ \\
\hline Additional fees & 34 & 636 & $1 ' 442$ & 49 & 191 & 450 & 358 & 507 & 68 & 200 & 400 & -278 & $-44 \%$ \\
\hline
\end{tabular}




\section{Table 5 (continued)}

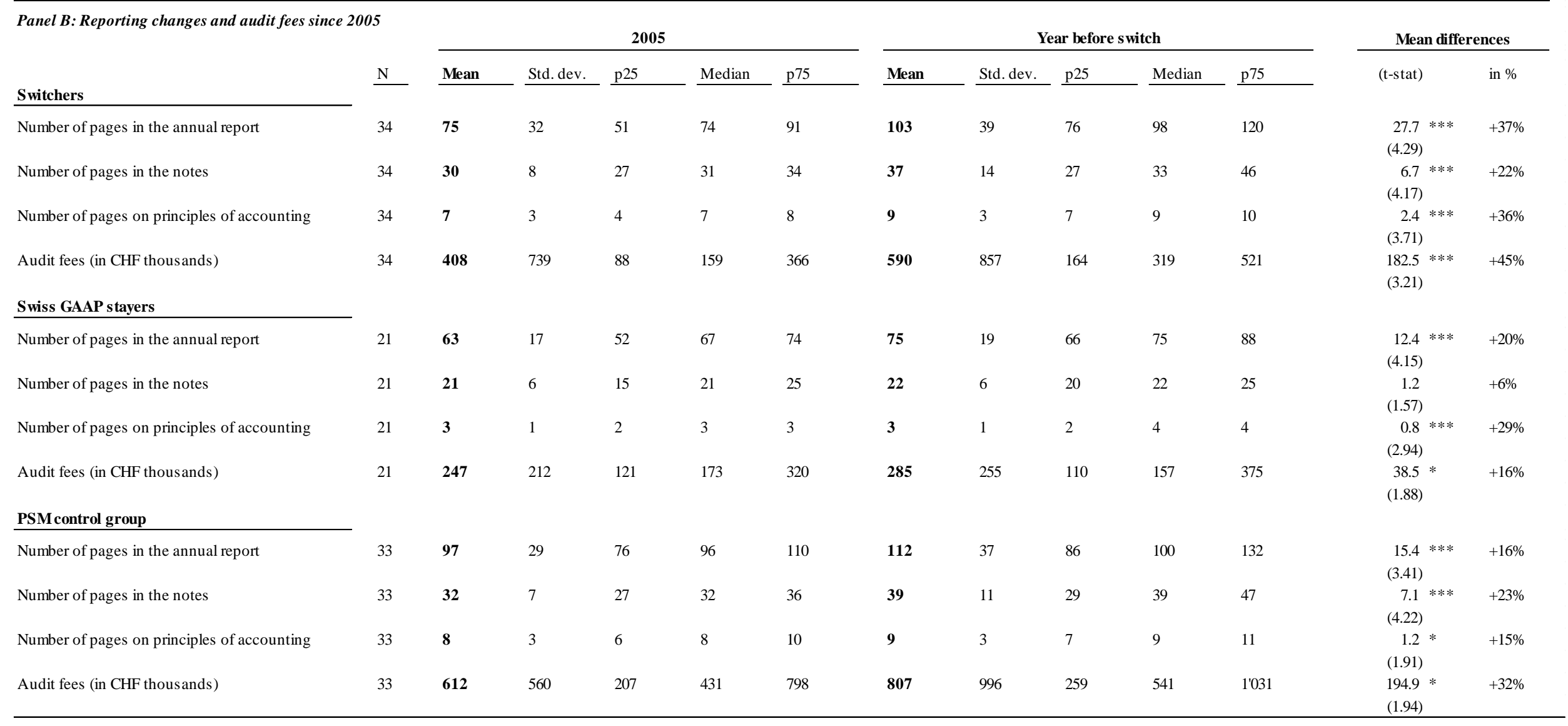

Panel A presents descriptive statistics on disclosed financial information in the annual report, disclosures on segment reporting, the reconciliation of shareholders' equity and net income from IFRS to Swiss GAAP, and the change in audit fees before and after switching from IFRS to Swiss GAAP. For the number of pages, words, and positions in the financial statements, as well as for changes in segment reporting and audit fees, we compare the last annual report prepared according to IFRS (e.g. 2012) to the first annual report prepared according to Swiss GAAP (e.g.,. 2013). For the PSM control group, we compare the IFRS report in the year before the matched treatment firm switches (e.g., 2012) with the IFRS report for the year in which the matched switching firm reports under Swiss GAAP (e.g., 2013). For shareholders' equity and net income, we compare restated IFRS amounts to reported figures in the first annual report under Swiss GAAP (e.g., 2013). In addition, the table shows the reconciliation of shareholders' equity and net income from IFRS to Swiss GAAP (i.e., adjustments for differences in goodwill accounting, pension accounting, tax effects, and other effects).

Panel B presents descriptive statistics on reporting changes (i.e., number of pages in the annual report, in the notes, and in the principles of accounting) and audit fees for the switching firms, the Swiss GAAP stayers, and the PSM control group in the year 2005 and the year before the matched treatment firms switch from IFRS to Swiss GAAP. ***, **, and * indicate that the means are significantly different at the $1 \%, 5 \%$, and $10 \%$ levels, respectively, using a twotailed $t$-test with paired data. 
Table 6. Univariate DID analysis of liquidity effects around the switch

\begin{tabular}{|c|c|c|c|c|c|c|c|c|}
\hline Panel A: Proportional bid-ask s & $\begin{array}{l}\text { ads } \\
\mathrm{N}\end{array}$ & $\begin{array}{l}\text { pre-announce } \\
\text { (a) }\end{array}$ & $\begin{array}{l}\text { post-announce } \\
\text { (b) }\end{array}$ & $\begin{array}{c}\text { sost-publicatior } \\
\text { (c) }\end{array}$ & $\begin{array}{l}\text { long-term } \\
\text { (d) }\end{array}$ & (b) - (a) & (c) - (a) & (d) - (a) \\
\hline (1) Switchers & 34 & 0.039 & 0.035 & 0.029 & 0.026 & $\begin{array}{l}-0.004 \\
(-0.84)\end{array}$ & $\begin{array}{l}-0.010 \\
(-1.45)\end{array}$ & $\begin{array}{l}-0.013 * * \\
(-2.72)\end{array}$ \\
\hline (2) Index control & 34 & 0.017 & 0.016 & 0.016 & 0.017 & $\begin{array}{r}0.000 \\
(-0.72)\end{array}$ & $\begin{array}{l}-0.001 \\
(-1.09)\end{array}$ & $\begin{array}{r}0.000 \\
(-0.13)\end{array}$ \\
\hline (3) Size- and industry-matched & 34 & 0.014 & 0.013 & 0.016 & 0.011 & $\begin{array}{l}-0.001 \\
(-1.24)\end{array}$ & $\begin{array}{r}0.002 \\
(-0.37)\end{array}$ & $\begin{array}{l}-0.003 * \\
(-1.72)\end{array}$ \\
\hline (4) PSM & 34 & 0.015 & 0.016 & 0.013 & 0.024 & $\begin{array}{r}0.001 \\
(-0.89)\end{array}$ & $\begin{array}{l}-0.002 * \\
(-1.85)\end{array}$ & $\begin{array}{r}0.009 \\
(-0.88)\end{array}$ \\
\hline (5) Swiss GAAP stayers & 34 & 0.041 & 0.040 & 0.036 & 0.033 & $\begin{array}{l}-0.001 \\
(-0.70)\end{array}$ & $\begin{array}{l}-0.004 * * \\
(-2.29)\end{array}$ & $\begin{array}{l}-0.007 * * * \\
(-4.24)\end{array}$ \\
\hline (1) - (2) & & $\begin{array}{l}0.022 * * * \\
(2.87)\end{array}$ & $\begin{array}{l}0.018 * * \\
(2.29)\end{array}$ & $\begin{array}{l}0.014 * \\
(1.72)\end{array}$ & $\begin{array}{l}0.010 * \\
(1.70)\end{array}$ & $\begin{array}{l}-0.004 \\
(-0.80)\end{array}$ & $\begin{array}{l}-0.009 \\
(-1.34)\end{array}$ & $\begin{array}{l}-0.013 * * * \\
(-2.76)\end{array}$ \\
\hline (1) - (3) & & $\begin{array}{l}0.025 * * * \\
(3.36)\end{array}$ & $\begin{array}{l}0.021 * * * \\
(2.81)\end{array}$ & $\begin{array}{l}0.014 \\
(1.62)\end{array}$ & $\begin{array}{l}0.015 * * * \\
(2.93)\end{array}$ & $\begin{array}{l}-0.003 \\
(-0.68)\end{array}$ & $\begin{array}{l}-0.011 \\
(-1.44)\end{array}$ & $\begin{array}{l}-0.010 * * \\
(-2.07)\end{array}$ \\
\hline (1) - (4) & & $\begin{array}{l}0.024 * * * \\
(2.79)\end{array}$ & $\begin{array}{l}0.019 \text { ** } \\
(2.08)\end{array}$ & $\begin{array}{l}0.016 * \\
(1.89)\end{array}$ & $\begin{array}{l}0.002 \\
(0.18)\end{array}$ & $\begin{array}{l}-0.005 \\
(-0.99)\end{array}$ & $\begin{array}{l}-0.008 \\
(-1.14)\end{array}$ & $\begin{array}{l}-0.022 * \\
(-1.94)\end{array}$ \\
\hline (1) - (5) & & $\begin{array}{l}-0.001 \\
(0.19)\end{array}$ & $\begin{array}{r}-0.005 \\
(0.61)\end{array}$ & $\begin{array}{l}-0.007 \\
(0.92)\end{array}$ & $\begin{array}{l}-0.007 \\
(1.36)\end{array}$ & $\begin{array}{l}-0.003 \\
(-0.66)\end{array}$ & $\begin{array}{l}-0.006 \\
(-0.81)\end{array}$ & $\begin{array}{l}-0.006 \\
(-1.22)\end{array}$ \\
\hline $\begin{array}{l}\text { Panel B: Zero returns } \\
\text { Group }\end{array}$ & $\mathrm{N}$ & $\begin{array}{c}\text { pre-announce } \\
\text { (a) }\end{array}$ & $\begin{array}{l}\text { post-announce } \\
\text { (b) }\end{array}$ & $\begin{array}{c}\text { jost-publicatior } \\
\text { (c) }\end{array}$ & $\begin{array}{l}\text { long-term } \\
\text { (d) }\end{array}$ & (b) - (a) & (c) - (a) & (d) - (a) \\
\hline (1) Switchers & 34 & 0.276 & 0.299 & 0.268 & 0.266 & $\begin{array}{l}0.024 \\
(1.07)\end{array}$ & $\begin{array}{l}-0.007 \\
(-0.29)\end{array}$ & $\begin{array}{l}-0.010 \\
(-0.56)\end{array}$ \\
\hline (2) Index control & 34 & 0.142 & 0.141 & 0.145 & 0.150 & $\begin{array}{l}-0.001 \\
(-1.26)\end{array}$ & $\begin{array}{l}0.003 \\
(0.15)\end{array}$ & $\begin{array}{l}0.007 * \\
(1.96)\end{array}$ \\
\hline (3) Size- and industry-matched & 34 & 0.144 & 0.135 & 0.157 & 0.165 & $\begin{array}{l}-0.010 \\
(-0.57)\end{array}$ & $\begin{array}{l}0.013 \\
(0.78)\end{array}$ & $\begin{array}{l}0.021 \\
(0.63)\end{array}$ \\
\hline (4) PSM & 34 & 0.155 & 0.172 & 0.200 & 0.215 & $\begin{array}{l}0.017 \\
(0.87)\end{array}$ & $\begin{array}{l}0.045 \\
(1.49)\end{array}$ & $\begin{array}{l}0.060 \\
(1.66)\end{array}$ \\
\hline (5) Swiss GAAP stayers & 34 & 0.450 & 0.457 & 0.438 & 0.432 & $\begin{array}{l}0.008 \\
(1.23)\end{array}$ & $\begin{array}{l}-0.012 * \\
(-1.77)\end{array}$ & $\begin{array}{l}-0.018 * * * \\
(-2.82)\end{array}$ \\
\hline (1) - (2) & & $\begin{array}{l}0.133 * * * \\
(3.04)\end{array}$ & $\begin{array}{l}0.158 \text { *** } \\
(3.47)\end{array}$ & $\begin{array}{l}0.123 * * \\
(2.55)\end{array}$ & $\begin{array}{l}0.117 * * \\
(2.35)\end{array}$ & $\begin{array}{l}0.025 \\
(0.92)\end{array}$ & $\begin{array}{l}-0.010 \\
(-0.31)\end{array}$ & $\begin{array}{l}-0.017 \\
(-1.04)\end{array}$ \\
\hline (1) - (3) & & $\begin{array}{l}0.132 * * * \\
(2.87)\end{array}$ & $\begin{array}{l}0.165 \text { *** } \\
(3.49)\end{array}$ & $\begin{array}{l}0.112 * * \\
(2.10)\end{array}$ & $\begin{array}{l}0.101 * \\
(1.73)\end{array}$ & $\begin{array}{l}0.033 \\
(1.20)\end{array}$ & $\begin{array}{l}-0.020 \\
(-0.66)\end{array}$ & $\begin{array}{r}-0.031 \\
(-0.82)\end{array}$ \\
\hline (1) - (4) & & $\begin{array}{l}0.121 * * \\
(2.60)\end{array}$ & $\begin{array}{l}0.127 * * \\
(2.60)\end{array}$ & $\begin{array}{l}0.068 \\
(1.14)\end{array}$ & $\begin{array}{l}0.051 \\
(0.81)\end{array}$ & $\begin{array}{l}0.007 \\
(0.23)\end{array}$ & $\begin{array}{l}-0.052 \\
(-1.34)\end{array}$ & $\begin{array}{l}-0.069 * \\
(-1.76)\end{array}$ \\
\hline (1) - (5) & & $\begin{array}{l}-0.174 * * * \\
(-4.36)\end{array}$ & $\begin{array}{l}-0.158 * * * \\
(-3.86)\end{array}$ & $\begin{array}{l}-0.169 * * * \\
(-3.80)\end{array}$ & $\begin{array}{l}-0.166 * * * \\
(-3.80)\end{array}$ & $\begin{array}{c}0.016 \\
(0.70)\end{array}$ & $\begin{array}{c}0.005 \\
(0.18)\end{array}$ & $\begin{array}{c}0.008 \\
(0.44)\end{array}$ \\
\hline
\end{tabular}

This table reports mean values and, in parentheses, t-statistics of the proportional bid-ask spread (Panel A) and the percentage of zero returns (Panel B) for the preannouncement, post-announcement, post-publication, and long-term period. Each period consists of 40 trading days before and after the switching announcement, after the publication of the first report under Swiss GAAP, and 2 years after publication (i.e., long-term).

Switchers are firms that announced their switch from IFRS to Swiss GAAP between 2008 and 2013. For the index control, each switching firm is matched to an index comprising the 107 firms that continue reporting under IFRS. For the size- and industry-matched sample, each switching firm is matched to an IFRS firms with similar size in the same industry. For the propensity score matched (PSM) sample, each switching firm is matched to an IFRS firm based on Model 6 in Table 4. For the Swiss GAAP stayers, each switching firm is matched to an index comprising the 29 firms that did not adopt IFRS.

$* * *, * *$, and $*$ indicate statistical significance at the $1 \%, 5 \%$, and $10 \%$ levels (two-tailed). 
Table 7. Multivariate DID analysis of liquidity effects around the switch from IFRS to Swiss GAAP

\begin{tabular}{|c|c|c|c|c|c|c|c|}
\hline \multirow{2}{*}{$\begin{array}{l}\text { Dependent variable: } \\
\text { Variables }\end{array}$} & \multirow{2}{*}{$\begin{array}{l}\text { Predicted } \\
\text { sign }\end{array}$} & \multicolumn{3}{|c|}{ Column A: Log(Bid-Ask Spread) } & \multicolumn{3}{|c|}{ Column B: Percentage of Zero Returns } \\
\hline & & (1) & (2) & (3) & (4) & (5) & (6) \\
\hline POST_ANNOUNCE & $?$ & $\begin{array}{l}-0.002 \\
(-0.02)\end{array}$ & & & $\begin{array}{l}0.020 \\
(1.62)\end{array}$ & & \\
\hline$P O S T \_P U B L$ & $?$ & & $\begin{array}{l}-0.025 \\
(-0.26)\end{array}$ & & & $\begin{array}{l}0.020 \\
(1.45)\end{array}$ & \\
\hline$P O S T \_P U B L \_8 Q$ & $?$ & & & $\begin{array}{l}-0.047 \\
(-0.62)\end{array}$ & & & $\begin{array}{l}0.014 \\
(1.26)\end{array}$ \\
\hline $\log \left(R E T \_V O L\right)$ & $+/-$ & $\begin{array}{l}0.474 * * * \\
(11.79)\end{array}$ & $\begin{array}{l}0.474 * * * \\
(11.82)\end{array}$ & $\begin{array}{l}0.469 * * * \\
(12.64)\end{array}$ & $\begin{array}{l}-0.071^{* * * *} \\
(-8.58)\end{array}$ & $\begin{array}{l}-0.071^{* * * *} \\
(-8.60)\end{array}$ & $\begin{array}{l}-0.068 * * * \\
(-7.90)\end{array}$ \\
\hline Log(SHARE_TURN) & - & $\begin{array}{l}-0.229 * * * \\
(-11.23)\end{array}$ & $\begin{array}{l}-0.229 * * * \\
(-11.28)\end{array}$ & $\begin{array}{l}-0.244 * * * \\
(-12.87)\end{array}$ & $\begin{array}{l}-0.037 * * * \\
(-10.20)\end{array}$ & $\begin{array}{l}-0.037 * * * \\
(-10.23)\end{array}$ & $\begin{array}{l}-0.036 * * * \\
(-10.18)\end{array}$ \\
\hline $\log (M V)$ & - & $\begin{array}{l}-0.358^{* * *} \\
(-8.93)\end{array}$ & $\begin{array}{l}-0.358^{* * *} \\
(-8.93)\end{array}$ & $\begin{array}{l}-0.372 * * * \\
(-10.04)\end{array}$ & $\begin{array}{l}-0.041 * * * \\
(-7.95)\end{array}$ & $\begin{array}{l}-0.041^{* * * *} \\
(-7.88)\end{array}$ & $\begin{array}{l}-0.039 * * * \\
(-7.96)\end{array}$ \\
\hline Constant & $?$ & $\begin{array}{l}1.075 \\
(1.46)\end{array}$ & $\begin{array}{l}1.072 \\
(1.45)\end{array}$ & $\begin{array}{l}1.255^{*} \\
(1.79)\end{array}$ & $\begin{array}{l}0.611 * * * \\
(6.24)\end{array}$ & $\begin{array}{l}0.615 * * * \\
(6.20)\end{array}$ & $\begin{array}{l}0.580 * * * \\
(6.16)\end{array}$ \\
\hline Quarter fixed effects & & Yes & Yes & Yes & Yes & Yes & Yes \\
\hline Firm fixed effects & & Yes & Yes & Yes & Yes & Yes & Yes \\
\hline Observations & & 4,633 & 4,633 & 4,450 & 4,633 & 4,633 & 4,450 \\
\hline R-squared & & 0.922 & 0.922 & 0.926 & 0.814 & 0.814 & 0.803 \\
\hline
\end{tabular}

The table reports coefficient estimates and, in parentheses, $\mathrm{t}$-statistics based on heteroskedasticity-robust standard errors clustered by firm (Petersen, 2009). The dependent variable for Models (1) to (3) is the natural logarithm of the median bid-ask spread in a given quarter from Q1 2008 until Q2 2015. For Models (4) to (6), the dependent variable is the percentage days of zero returns in a given quarter from Q1 2008 until Q2 2015. POST_ANNOUNCE and POST_PUBL are dummy variables equal to 1 for all quarters of a firm after its announcement to switch and after its publication of the first report under Swiss GAAP, respectively. $P O S T_{-} P U B L \_8 Q$ is a dummy variable equal to 1 for a maximum period of eight quarters of a firm after its publication of the first report under Swiss GAAP. $R E T_{-} V O L$ is the standard deviation of logarithmic daily stock returns in a given quarter. SHARE_TURN is the quarterly median of daily share turnover (i.e., traded shares divided by total outstanding shares). $M V$ is the stock price muliplied by the number of outstanding shares. $* * * * *$, and $*$ indicate statistical significance at the $1 \%, 5 \%$, and $10 \%$ levels (two-tailed). 
Table 8. Analysis of stock returns around the switching announcement

\begin{tabular}{|c|c|c|c|c|c|}
\hline & $\mathrm{N}$ & & Returns & & \# of negative \\
\hline & & {$[0,1$ day $]$} & {$[0,2$ days $]$} & {$[-5$ days, 5 days $]$} & \\
\hline Raw & 34 & $\begin{array}{l}0.002 \\
(0.52)\end{array}$ & $\begin{array}{l}0.004 \\
(1.02)\end{array}$ & $\begin{array}{l}-0.003 \\
(-0.24)\end{array}$ & $(14,19,19)$ \\
\hline Index-adjusted & 34 & $\begin{array}{l}-0.001 \\
(-0.21)\end{array}$ & $\begin{array}{l}0.001 \\
(0.20)\end{array}$ & $\begin{array}{l}-0.006 \\
(-0.50)\end{array}$ & $(19,17,19)$ \\
\hline Size- and industry-adjusted & 34 & $\begin{array}{l}0.004 \\
(0.66)\end{array}$ & $\begin{array}{l}0.009 \\
(1.31)\end{array}$ & $\begin{array}{l}0.015 \\
(0.72)\end{array}$ & $(17,15,15)$ \\
\hline PSM-adjusted & 34 & $\begin{array}{l}-0.003 \\
(-0.39)\end{array}$ & $\begin{array}{l}-0.007 \\
(-0.82)\end{array}$ & $\begin{array}{l}0.006 \\
(0.52)\end{array}$ & $(16,14,18)$ \\
\hline Swiss GAAP-adjusted & 34 & $\begin{array}{l}0.002 \\
(0.58)\end{array}$ & $\begin{array}{l}0.003 \\
(0.65)\end{array}$ & $\begin{array}{l}-0.005 \\
(-0.37)\end{array}$ & $(20,18,20)$ \\
\hline
\end{tabular}

The table reports mean values and, in parentheses, t-statistics of cumulative raw, index-adjusted, size- and industry-adjusted, propensity score-adjusted, and Swiss GAAP stayers-adjusted stock returns for switching firms around the announcement date. Results are reported for three different event windows: [0,1day] is the announcement day; [0, 2days] is the period of the announcement and the following trading day; [-5days, 5days] are the five trading days before and after the announcement. \# of negative is the number of negative returns of switching firms for the different event windows. 